\title{
The Significance of Religious Education in Local Primary Schools (Specific Reference to Christianity)
}

\author{
Flourish Itulua-Abumere \\ In (Partial) Fulfillment of the Requirements for the Degree Doctor of Biblical Studies Approved For The \\ University
}

\begin{abstract}
In the contemporary context of studying religious education in a secular society, the process such as individualization makes it harder for children to get the opportunity to learn from religion in an organized way. At school young students can learn in an orderly and beneficial way from religion. However, we hardly know how they are making progress on this subject and what the significance of their participation in this subject really is. Currently, religious education at primary schools in Western Europe has evolved into a subject that seeks to support students to develop their religious identity. From a socio-cultural perspective, religious education aims to support students to develop their religious identity by giving them the opportunity to participate at religious practices. Religious tradition such as Christianity involve religious practices such as praying, gathering, taking care of the fellow men, dealing with life and death, or the interpretation of religious stories. In these practices the reality that surrounds us is related to the transcendent reality of God the only reliable tool that is use in their study is the bible. Here religious people use concepts like God, creation, nature, redemption, or eternity, and strategies as interpretation, symbolization or imagination. From this perspective, progress in religious education refers to participation at religious practices in a more expert way. The aim of this research is to get a clear view on the significance of studying Christian Religious Education (CRE) in primary school by gathering all the available evidence and the influences this education has had on the way they live their lives, communicate with the secular world and to bring to light factors that help to explain this significance. Is there any benefit of religious education in schools? And how does it affect the child? Are the implications positive or negative? What is the progress of these students? To be more precise, what are the learning effects in Christian religious education of these students at the various levels of the primary school regarding their understanding of religion? And secondly, which factors are enhancing and which are diminishing this progress?
\end{abstract}

Index of figures and tables

\section{Contents}

Acknowledgement

Abbreviations

Introduction

\section{Chapter 1}

Thesis Question

Aims and Objectives

What is Religious Education?

The purpose of Religious Education

Attitudes in Religious Education

Christianity as a Religion

Chapter 2

Main grouping of Christianity

Jesus Christ

Death and Resurrection of Jesus

Christian Education

Benefits of Christian Education

Christians Involvements in Education in the past

The need for Christian perspectives today

The General objectives of Christian Education

Various aids to Christian Education

Chapter 3

Importance of schooling 
Moral and Religious Education in Schools

Catholic Schools

The use of Bible in Christian Education

Bible Courses

The Major Issues

History of the Bible

\section{Chapter 4}

Christian Religious Education in primary School Curriculum

Theme 1: God and the creation of the world

God's Creation

Human beings share in God's creative activities

Biblical account of the first human disobedience

Conclusion

Chapter 5

References

Index of Figure and Tables

Figure 1: Attitudes in Religious Education

Figure 2: Christianity

Figure 3: Major branches within Christianity

Figure 4: Derivation of major branches

Figure 5: Christian worldview

Figure 6: Purpose of Christian Education

\section{Acknowledgment}

I wish to express my profound gratitude to Almighty God for his guidance, protection and provision during my sojourn in this Ivory tower for my research

I am particularly grateful to my supervisors, Professor James Gurl, Professor Mitch King and the entire faculty members for their invaluable supervisory role throughout the duration of this thesis.

I will not also fail to appreciate the support of my family, friends especially my Husband, Father and Mother who have supported me physically and spiritually and to all students of Bible University for their friendship and support while I worked on this thesis.

\begin{tabular}{|c|c|}
\hline & Abbreviations \\
\hline QCDA & Qualifications and curriculum Development Agency \\
\hline BHA & British Humanist Association \\
\hline QCA & Qualification and Curriculum Framework \\
\hline DCSF & Department for Children, Schools and Families \\
\hline KJV & King James Version \\
\hline EDT & Evangelical Dictionary of Theology \\
\hline DFES & Department for Education and Skills \\
\hline RE & Religious Education \\
\hline OFSTED & Office for Standards in Education, Children's Services and Skills \\
\hline NFRE & National Framework for Religious Education \\
\hline $\mathrm{CE}$ & Christian Education \\
\hline 1 Cor & 1 Corinthians \\
\hline Eph & Ephesians \\
\hline Col & Colossians \\
\hline Ecc1 & Ecclesiastes \\
\hline BibRes & Biblical Research \\
\hline EJT & European Journal of Theology \\
\hline JBR & Journal of the Bible and Religion \\
\hline JSSR & Journal of Scientific Studies of Religion \\
\hline NT & New Testament \\
\hline OT & Old Testament \\
\hline SJT & Scottish Journal of Theology \\
\hline Ps & Psalm \\
\hline Gal & Galatians \\
\hline
\end{tabular}




\section{Introduction}

Religious education forms part of the basic national curriculum for primary schools this may be a surprising fact but it has come up to be the truth and nothing but the truth. Some individuals have linked religious with social habituation and they have also gone a long way to argue that it has no consign in either a working environment or a schools. At the same time, others believe religion in education have to be about fostering students within a meticulous religious faith system. Over the year's religious education has actively been known to be a strong promoter of the values of genuineness, fairness, honesty, deference for all and care of the environment. Religious education consign specific emphasis on children appreciating themselves and others, it teaches us the real responsibility of family and the community in religious principle and action, the contentment of diversity in society through of acknowledgment of their similarities and differences, and individual custodianship on earth. Religious education is also acquainted with shifting environment of the general public, including transformations in religious practice and appearance and the authority of religion in the neighborhood, homes, state and in the universal society. (QCDA, 1993)

The study of religious education with children helps to develop the children knowledge and understanding of Christianity and in some cases, not just Christianity but also other religious cultures and other belief systems. Previous studies have also shown that religious education has encouraged children to learn from various religious beliefs, values and culture while at the same time, exploring their own beliefs regarding their religion. This comprehensive study in primary schools has also help children to mature personally and socially as well as refining their psychological judgments and decisions on religious, moral and social issues, preparing them for life in a secular society.

During my time in primary school I can clearly recall that Christian religious education popularly known as (CRE) was a compulsory subject for us we had no right at that time to make it an optional subject. It was also mandatory to pass it although it wasn't compulsory that you had to pass it before you can get promoted to the next class. This curriculum schedule gave us no other option than to study as pass it. In fact anyone who could not pass CRE is assumed not to be able to do well or pass other subjects. This education gave us a stronger sense of our own identity and it made us to know our place in the world that we live in through the religious and ethical teaching. For those of us who just gained admission into primary school the subject was not just at a personal level anymore but was also aimed at make these students understand how the community they live in functions religiously, socially, politically and culturally. At the end of the day, these new admitted students are encouraged with such religious education to develop a sense of societal unity and communal accountability in the direction of others. (Lopez-Muniz, et al., 2006)

Let's talk about Great Britain and religious education for a bit. Great Britain is known to be a multicultural society for decades now. Religious education in their primary schools has been made compulsory for registered students under the Education Act 1996. Nevertheless, parents and guardians can make an informed decision to withdraw their children out of a particular religious education subject. Meaning if a child is Christian and the parents do not wish that child to participate in Islamic studies that child can be automatically withdrawn from that subject if the parents chooses that. Following instructions from a locally agreed syllabus, schools must ensure that religious education is been taught according to the agreed syllabus. Voluntary aided schools are exempted from this anyway. The main and major religious tradition in UK is Christianity. So for that reason, each concurred syllabus should consider and put that fact into consideration when conducting teaching classes and practices of other religious education areas in UK. (Lopez-Muniz, et al., 2006)

Regarding inclusion, religious education has made a significant involvement principally in its center of attention on promoting value for everyone equally. Religious education has taken a front responsibility in fighting against injustice, unfairness and pessimistic bias. By teaching or providing religious education to children who just begin primary school means you have just opened the doors to moral development for them. Religious education is a good preliminary point for them and it's a fundamental way to meet their explicit requirements as this will help to caution them all the way through until they graduate to the next level. (Barnes, 2001) When planning religious education curriculum that will be used in primary school for first year students, the school authority have to put into consideration three principal philosophies that are crucial to the progress of a more comprehensive syllabus:

- Make provision for appropriate learning challenges

- Act in response to students miscellaneous study requirements

- Endeavour to conquer likely difficulties to study and examination for persons and group of students

It is widely deemed that religious education build up awareness of major world religions such as Christianity, Islam, and Buddhism and as well opening doors for individual expression and sacred maturity. It:

- It aggravate demanding subject about the crucial significance and function of life, faith in God, moral issues and what it means to be human.

- It boosts students' consciousness of religious convictions and values, education and outward appearance of expression, as well as the influence of faith on persons, families, societies and traditions. 
- It encourages primary school students to study from different religions, way of life, ethics and customs whilst investigating their own beliefs and questions of significance.

- The ideal confronts students to reflect on, think, evaluate, understand and appraise on issues of reality, belief, devotion and moral values and to communicate their response.

- It gives confidence to students; help them to expand their own sense of reasoning and belonging. They are able to prosper independently as persons within their society and as nationals in a pluralistic society.

- Religious education has an important role to also play in the area of planning students for transition into adulthood and lifelong education.

- Religious education also facilitates students to build up value and compassion to others, especially those whose faith and way of life are dissimilar from their own. It helps to encourage positive judgment and enables students to fight against discrimination.

Once upon a time an Author called Greer in 1972 made available a series of his papers publication on religious education in post primary schools. One of the main principal areas he concentrated on was on sixth formers in post primary schools. He is a known writer for religious education especially for primary schools. In one of his papers, he accounted on an analysis of 16 schools that were protestant and another 12 that were predominantly catholic's primary schools. During his research, he discovered the normal duration exhausted on religious education in the former was just approximately 23 minutes in one lesson class in a whole week contrast with 91 minutes spent weekly in the latter. This was also confirmed by other writers (Teare and Sutherland) in there publication in 1988.

For that reason the Author Greer concluded by affirming this words:

"Traditional biblical syllabuses for primary schools were products of their time and it is understandable that they often failed to take children's' development and limited experience into account. What is disturbing about recent biblical syllabuses produced in Northern Ireland is the ignorance they still reflect of commonly accepted knowledge of children in state Protestant schools in Northern Ireland it has long been assumed that the aim of Religious Education should be confessional or evangelical" (Greer 1978, pg 11-16; Greer 1979, pg 7-11) Another paper written by Greer and Brown in 1981, later stresses the divisive scenery of religious education in primary schools which he assumed as one or the main reasons for the feeble nature of religious education in Great Britain scheme of assessment that is made available. (Quoted in Gallagher, 2009)

So far so good, there is still one major area where intensive study on primary schools appears to be lacking and that is in the area of religious education. It has been seen that over the years more research is going on in this area but it is still very minute compared to how it should be. Even though it is feasible to illustrate two comparable religious school systems, there is reasonably slight substantiation on the level of religious homogeneity within those systems.

\subsection{Research Questions}

- What are the significances of religious education in primary schools?

- How important is it to include religious education to primary school curriculum?

- How should a religious education syllabus be laid out for beginners in primary school students? Using Christian Religious Education as a reference

- What are the outcomes for studying religious education in primary school?

\subsection{Aims And Objectives Of Thesis}

For years now, I have taken a close look at the nature of religious education in my country and I have compared it to other countries that do not include or make religious education a compulsory subject that should be taught in primary schools. I have seen reasons behind the success of those who teach or include religious education in their curriculum. My major aim in this thesis is to gather all the evidence that illustrates the usefulness of teaching religious education in our modern primary schools, the benefits it has to parents, teachers, and society at large, it also aim to expose the purpose and nature of such education in our community. In as much as so many people know the importance of studying religious education from early years to youth age there are also millions of people out there that are completely ignorant of its importance and see no reason for religious education in our schools. My aim is to reshape their knowledge about the topic and make them see why they should support and encourage their children, relative and other people living there community to participate in religious education because the advantages are countless.

My first objective is to introduce the importance using literature reviews, then formulate a religious education curriculum format for those in six form primary school. For schools who do not have a syllabus for Christian religious education this can be useful starting point and tool for them to begin with. I have chosen to contrite my writing with specific reference to Christianity because I was a Christian and am still a Christian living in a Christian society. At the end of the thesis, teachers and parents should find this paper useful in structuring and planning Christian religious education syllabus and they will also be able to know why it's 
necessary to encourage young children to participate in religious education. My formulated syllabus will include useful themes and topics, moral lessons and questions. No doubt if you are a reader you will find out that Christian religious education will make a child a better and useful person in the society because they are lot of moral lessons to be learnt in Christian religious education and the bible will be the major tool that we will depend on to achieve knowledge.

\subsection{What Is Religious Education?}

Under normal circumstance, religious education can be defined as a lesson, instruction or coaching of a specific religion. In contemporary and secular society, religious education involves a particular kind of teaching which is so much not associated with the academic world and usually considers religious faith as the basic ideology and working modality, as well as a required condition of attendance. We can also say that religious education is a phrase given to education concerned with the study of religion. It can be referred to the teachings achieved through a church or religious association for information with regards to doctrinal beliefs and faith, or for learning in various areas of religion, but with no unequivocally religious or ethical aspires, e.g. in a school, college or university. The expression frequently has common characteristics with religious studies. (Wikipedia, 2010)

\section{Great Britain}

In Great Britain religious education is a mandatory subject in the state educational system. Primary schools are obligated to educate students on a religious studies curriculum of according to the local and national standard guidelines. In Scotland there educational systems for primary and secondary schools have divided religious education into two categories. The first is for age 5 to 14 and the other from age 14 to 18 . Age 5 to 14 is required to study Religious and Moral Education while age 14 to 18 is required to study Religious, Moral, and Philosophical Studies. In England, religious education is a compulsory subject that is taught to primary and secondary school students under the 1944 Educational Act which was later amended as Education reform Act 1988 and most recently amended as School Standards and Framework Act 1998. Religious education is also obligatory in all state financed schools. When studying religious education, the instructor does not just teach one religion like Christianity. It comprises of diverse religions. The teachings usually cover religious leaders, the creation of the world in a particular religious perspective, religious and moral themes. Though, the syllabus is mandatory to reveal the principal situation of Christianity in religious existence and for this reason Christianity forms the most important of the content of the subject. Parents and guardians have the right to exempt their children from participating in religious education anytime during the period of study, of which the school authority have no right to disallow. (Department of Children, Schools and Families, 2008)

Schools in Great Britain are required to conduct a on a daily basis act of worship according to educational system law, of which at least 51 percent who participates must be Christians in the beginning over the course of the academic year. This organized activities may seems multi faith in nature but it is usually pointless and worthless to those who do not practice Christianity particularly those who are Muslims due to the fact that they have a totally different way of worship and conducting their prayers. The association of teachers in Great Britain have condemn the act of school worship and called for a government appraisal of the practice. (BHA, 2006) with all this involved, students that are age aged 16 and above will still need an informed consent from their parents to pull out from such collective prayers. Due to lack appropriate support from teachers and the government of the state reluctance to magnetize controversy, only a quarter of secondary school for instance actually meets the terms and conditions of the code of practice and standards of the education inspectorate OFSTED. (Wilkins, 2005)

In Scotland the educational system states national procedures which state expectations of pupils learning. The local authorities in each part of Scotland will sketch a syllabus for each of its schools. Whilst in England, each and every local authority has a confined decided curriculum which gives authorization to subject teaching for each key stage and if possibly for each year. In England, the Qualification and Curriculum Authority (QCA) is responsible for approving schools and colleges and they have made provision for religious education studies across the country by providing a non-statutory National Framework for Religious Education, which gives strategies and standards for the stipulation of religious education at all key phases, and forms the eight-levels as functional in National Curriculum subjects. (Qualification and Curriculum Authority, 2004)

In 2008, the National Union of Teacher (NUT) recommended that parents and guardians should possess the right and privileges to particular education in their personal faith and that imam, rabbis and priest can be encourage to come and offer religious tutoring to students in all state schools. (Goff, 2008)

\subsection{The Purpose Of Religious Education}

The purposes of studying religious education are numerous. However, that will not prevent me from stating some of the most crucial purposes. The first of these purposes refers to the function of religion as component of the general curriculum. England and Wales has made religious education a mandatory subject for 
students to study in schools as obligated by law. Religious education forms part of their fundamental curriculum which has to be taught to all students of all required school age, and ahead of the least school leaving age. It is made available to students who hail from strictly religious family settings and also to those who are not. This purpose refers to the general learning result or outcome of religious education, so therefore it can be expressed as making participation to all students. In this situation students are not considered to be believers or non believers but as students in general. (Hull, 1993)

The second purpose is the fact that religious education provides individuals understanding to those who are religious in nature. Previous studies have made clearer difference between the responsibilities of religious nurture (the fostering of religious faith) and that of religious education in contributing to a significant perception on the scenery of religion.

This peculiarity, though still valuable, is conceivably excessively clear. We have to realize early enough compared to previous ten year ago that religious education does not have an involvement in creating or building up encouragement of faith as well as in education of the secular person. Religious education is not intended to be beneficial to only those who are spiritual or religious, if it happens to so it will seem more like a bizarre practice. Off course it encourages students who are already from religious families but also is a starting point for those who are still not from religious homes. So what kind of encouragement do you think religious education can provide for young people in today's society? It will obviously consist of the verification of their personality. It will also offer them the chance to fit into place in the study of their own culture along with the culture of other young children like themselves. Putting this into consideration, the students will be able to assess their self indulgent. Religious education will make an input towards their personal development and maturation as religious advocate ready to take a mature and intelligent part in fully developed society. (Hull, 1993)

\subsection{Attitudes In Religious Education}

The skills, understanding and knowledge acquired from religious education in our schools is very vital to the National Framework for Religious Education, it is also important that religious education positively supports students to mature in their attitudes positively to their learning and to the beliefs and values of others. Below are four attitudes that are very fundamental for excellent and high quality learning in religious education and should be developed at each stage and step of religious education:

- Self understanding

- Value for all

- Open-mindedness

- Appreciation and wonder

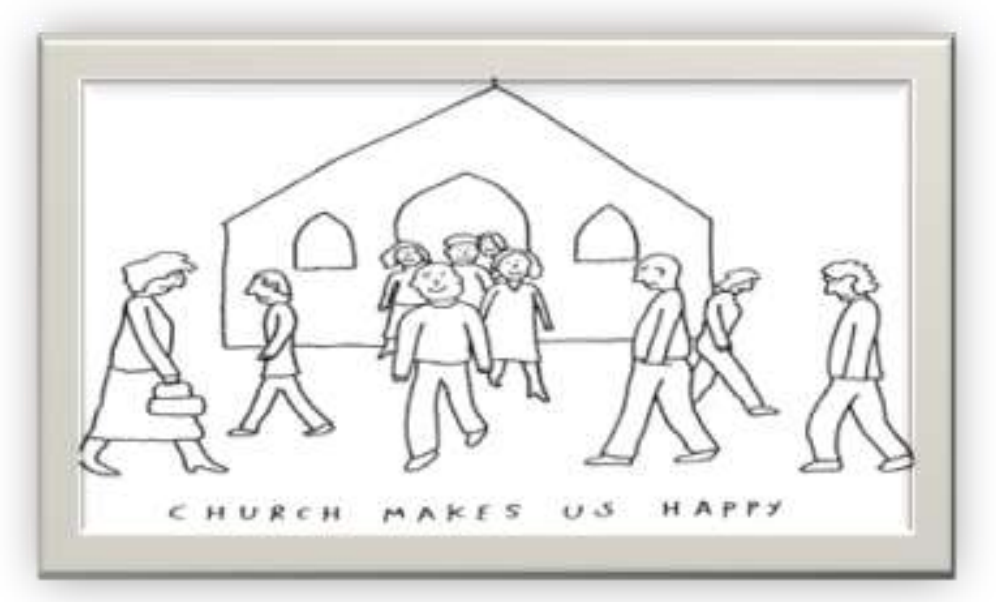

(Figure 1)

Self-understanding in religious education includes students:

- Experiencing self-assurance about their own beliefs and identity and distributing them with no fear of humiliation or mockery

- Increasing a reasonable and optimistic sagacity of their own religious, moral and spiritual ideas

- Recognizing their own uniqueness as human beings and confirming their confidence

- Becoming progressively more susceptible to the impact of their ideas and behavior of other people 
Value for all in religious education includes students:

- Developing proficiency of listening and a enthusiasm to learn from others, even when others' scrutiny are different from their own

- Being ready to value variation and diversity for the common good

- Understanding that some beliefs are not comprehensive and bearing in mind the issues that this raises for persons and society

- Being prepared to recognize and acknowledge their own prejudice

- Being insightful to the thoughts and ideas of others

Open-mindedness in religious education includes students:

- Being willing to learn and gain new understanding

- Engaging in argument or disagreeing reasonably and respectfully about religious, moral and spiritual questions

- Being willing to go beyond surface impressions

- Distinguishing between opinions, viewpoints and beliefs in connection with issues of conviction and faith

Appreciation and wonder in religious education includes students:

- Developing their thoughts and inquisitiveness

- Recognizing that knowledge is bounded by mystery

- Appreciating the sense of wonder at the world in which they live

- Developing their competence to act in response to questions of sense and rationale

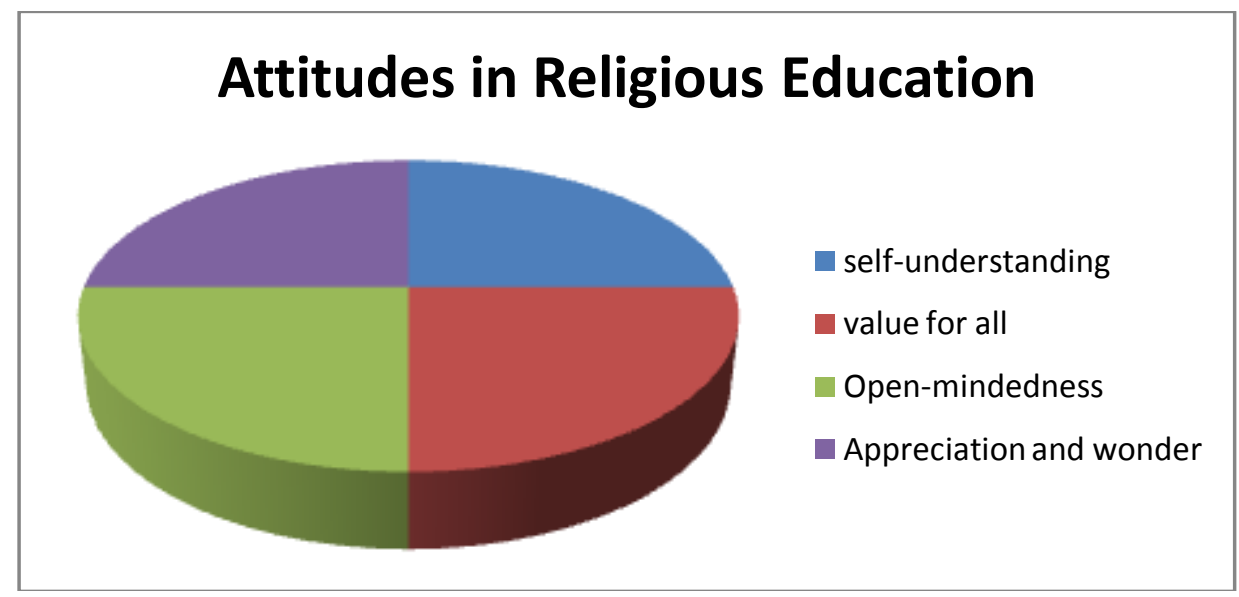

(Figure 2)

(Qualifications and Curriculum Authority, 2004)

\section{Christianity}

\section{Chapter}

The word Christianity originated from the Greek word Khristos, which literally means a monotheistic religion that is based on the existence, traditions and teachings of Jesus Christ of Nazareth as illustrated in the New Testament. Those who practice Christianity are called Christians. Christians believe that Jesus is the Son of God, and that God became Man and was born into earth as the savior of humanity. Christians consequently usually and frequently refer to Jesus as Christ or Messiah. (Briggs, 1913)

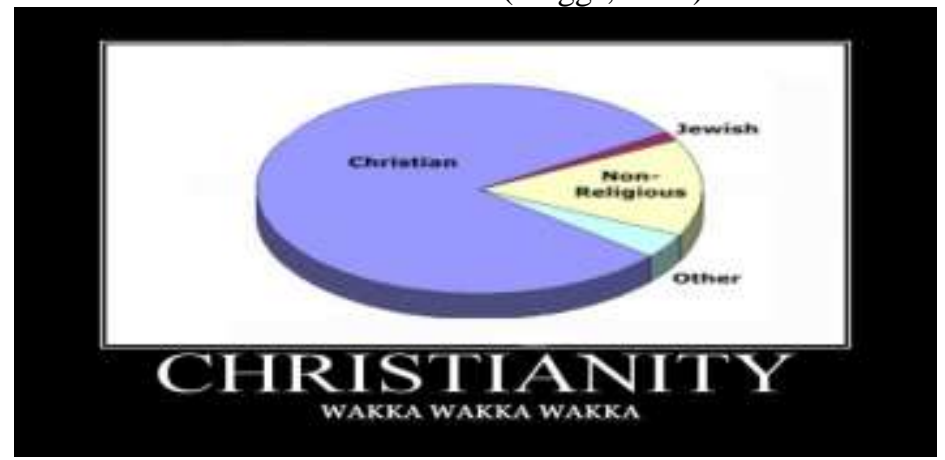

(Figure 3) 
Supporters of the Christian belief, commonly known as Christians, believe that Jesus is the Messiah forecasted in the Hebrew Bible or the Old Testament. The basis of Christian religion is articulated in the early Christian ecumenical faiths, which contain claims principally accepted by supporters of the Christian faith. These professions state that Jesus suffered, died from crucifixion, was buried, and resurrected from the dead to descend into the heavens to those who believe in him and trust him for the remission of their sins. Jesus Christ bodily ascended into heaven where he rules and reins with God the father almighty. Most denominations educate believers that Jesus will revisit to judge all humans, living and dead, and endow external life to his supporters. They went further to say that Jesus is the model of a righteous life, and both the revealer and physical manifestation of God. Christians identify the message of Jesus Christ the Gospel and hence refer to the initial written accounts of his ministry as gospels. (Duane, 1991)

Christianity began as a Jewish faction and is categorized as an Abrahamic religion which originated from the eastern Mediterranean. It wasted no time spreading in size and influence over a few decades, and by the fourth century Christianity has become a the most dominant religion within the Roman Empire. Most part of Europe has been Christianized during the middle ages. The religion Christianity is also said to be a minority religion in some part of the world such as Middle East, North Africa, and parts of India. Subsequent to the age of discovery, through missionary work and colonization, Christianity spread to the Americas, Australasia and the rest of the world, therefore Christianity is a major influence in the shaping of Western civilization and development. (Rhodes, 2005)

In the early twenty-first century, Christianity recorded an estimate that ranged between 1.5 billion and 2.2 billion believers. Christianity symbolizes about a quarter to a third of the world's population and is the world's largest religion. In addition, Christianity is the state religion of numerous countries as well as the fastest growing religion in the world. (Pamela, 2004)

\subsection{MAIN GROUPING OF CHRISTIANITY}

There are four major divisions of Christianity and this includes Roman Catholicism, the Orthodox Church, Anglican, and Protestantism. Other Christian groups exist but they do not fit into these primary categories. The Nicene Creed is accepted as reliable and convincing by the Roman Catholic, Eastern Orthodox, Anglican, and major Protestant churches. There is a range of doctrines and practices among groups calling them-selves Christians. These collections of people are occasionally classified under denominations, though for theological reasons many groups refuse this categorization system. An additional dissimilarity that is occasionally linked up is between Eastern Christianity and Western Christianity. (Creed, 2007)

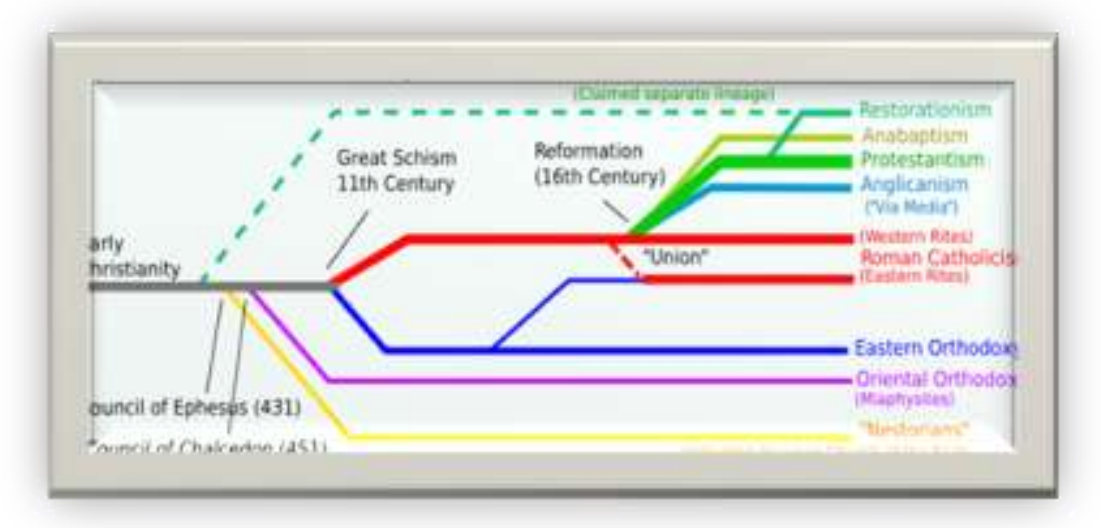

(Figure 4) The diagram below demonstrates derivation of major branches of Christianity.

Eastern Christianity

- Eastern Orthodox Church

- Oriental Orthodoxy

- Assyrian Church of the East

Catholic Christianity

○ Latin Rite (Western Rite or Roman Catholic)

- Eastern Catholic Churches

Western Christianity

o Protestantism

- Anglicanism

- Restorationism (note, this is a very diverse group) 


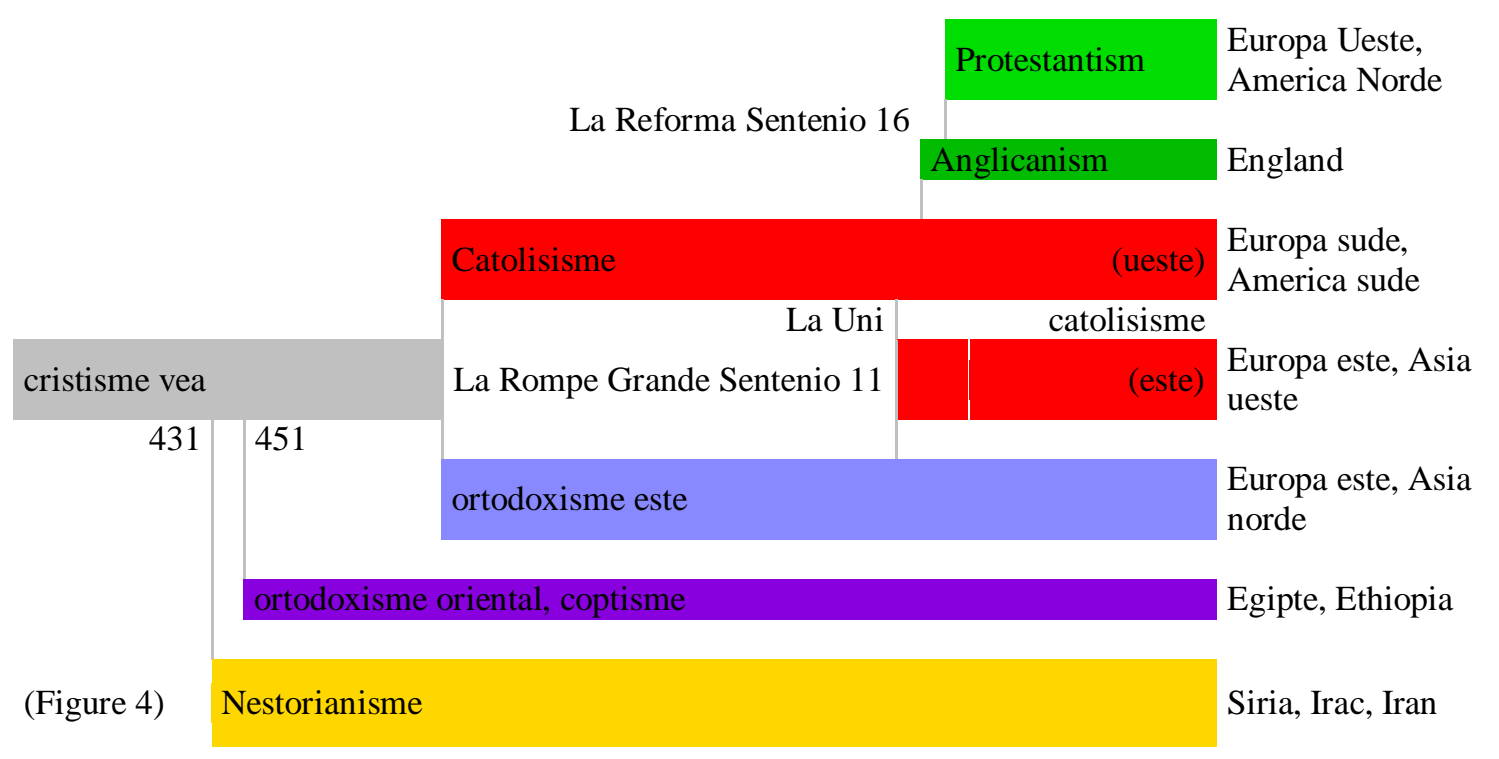

\subsection{Jesus Christ}

The fundamental ideology of Christianity is based on the belief of Jesus Christ as the son of God and the fore seen Messiah. The word Messiah originated from the Hebrew word meaning 'anointed one'. The Greek meaning is the resource of the English word 'Christ'. (Wright, 1997) Christians accept the true that Jesus as the Messiah was anointed by God as a redeemer of humankind, and hold that Jesus coming was the accomplishment

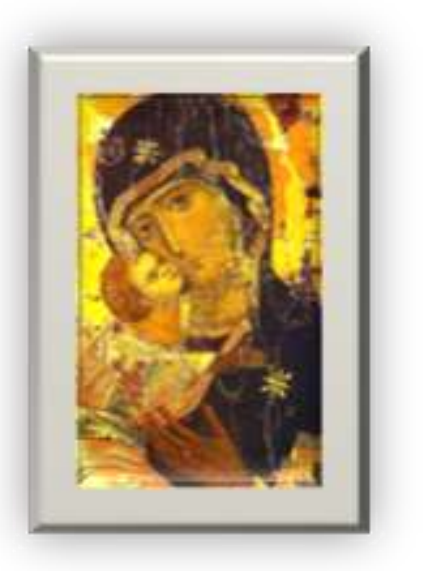
of messianic prophecies of the Old Testament. There is a significant difference between the Christian concept of the Messiah and that of the contemporary Jewish concept. The core Christian faith is in and recognition of the death of and resurrection of Jesus, sinful humans can be prepared to accept God and thereby are offered salvation and promise of eternal life. (Wright, 1997)

In the earliest centuries of Christian history, there have been numerous theological disputes. In general, Christians consider Jesus as God incarnate and true God and true man. They also see him as fully divine and fully human. Jesus having become entirely human, suffered the throbbing and temptations of a earthly man, but did not sin. As fully God he rose to life again. According to the bible, God raised him from the dead, and he ascended into heaven, for He is seated at the right hand of God the father almighty and will in due course revisit (Act 1:9-11) to accomplish the rest of Messianic prophesy such as the restoration of the dead, the final judgment and final establishment of the Kingdom of God. (Elliott, 1990)

The bible teaches us according to the Gospel of Matthew and Luke that Jesus was conceived by the Holy Spirit and born from the Virgin Mary. Not much of Jesus birth and early days was documented in the canonical Gospels, though, early Gospel were popular in ancient times. In contrast, his adulthood, particularly the week before his death, are well documented in the Gospels contained within the New Testament. The Biblical accounts of Jesus ministry includes: his baptism, miracles, preaching, teaching and performance (Milton, 1974)

\subsection{Death And Resurrection Of Jesus}

The resurrection of Jesus is seen in Christianity as the cornerstone of Christian's faith in God and one of the most important occasion in human history (I Corinthians 15). Within the Christian faiths, the death and resurrection of Jesus are two center events on which a large amount of Christian doctrine and theology is based. According to the New Testament Jesus was crucified, died a physical death and was buried within a tomb, and rose again from the dead three days afterward. The New Testament talk with reference to more than a few resurrection appearance of Jesus on various events to his twelve apostles and disciples, including more than five hundred brethren at once before Jesus ascension into heaven (1 Corinthians 15:6) The death of Jesus and his resurrection are remembered by Christians in all devotional worship services, with extraordinary importance during Holy Week which includes Good Friday and Easter Sunday (Elwell, 1984). 
The history of Christianity has recorded the death and resurrection of Jesus as the most important event in Christian Theology, simply because they make obvious the reason why Jesus has power over life and death and for that reason has the authority and power to give people eternal life. (John, 2000)

Christian churches accept and teach the New Testament version of the resurrection of Jesus with very little exceptions. Some contemporary intellectuals use the belief of Jesus supporters in the resurrection as a point of exit for establishing the permanence of the historical Jesus and the proclamation of the early church. Some open-minded Christians do not believe a factual physical resurrection, seeing the account as luxuriantly representational and spiritually nourishing fairy tale. Argument over death and resurrection claims occurs at many religious debates and interfaith discussion (Cross, 1997). Paul the Apostle, an early Christian convert and missionary, wrote, "If Christ was not raised, then all our preaching is worthless, and your belief in God is worthless." (1 Corinthians 15:14)

\subsection{Christian Education}

Christian Education sees education both as an official, institutionalized process in schools, colleges, universities, workplaces and faith communities and as unofficial development of nurture and development in homes and communities through the media and critical manifestation on lived experience. Young people need to be equipped with the appropriate knowledge needed in today's society, necessary skills needed to face our challenging society and principles which will help them handle with the understanding, opportunity and complications of becoming an adult. For Christian Education, maturity is more a developmental concept than a motionless differentiation, the identification of independence, sovereignty and yet connectedness with others and the surroundings. Its existence, or nonexistence, can be eminent at any age. Non-formal educations in churches make an impact greatly towards Christian education, with the experience and significance of worship playing a principally influential role for children and young people. Church education programs and other children's and youth work also contribute to the growth of Christian discipleship. (Milton, 1974)

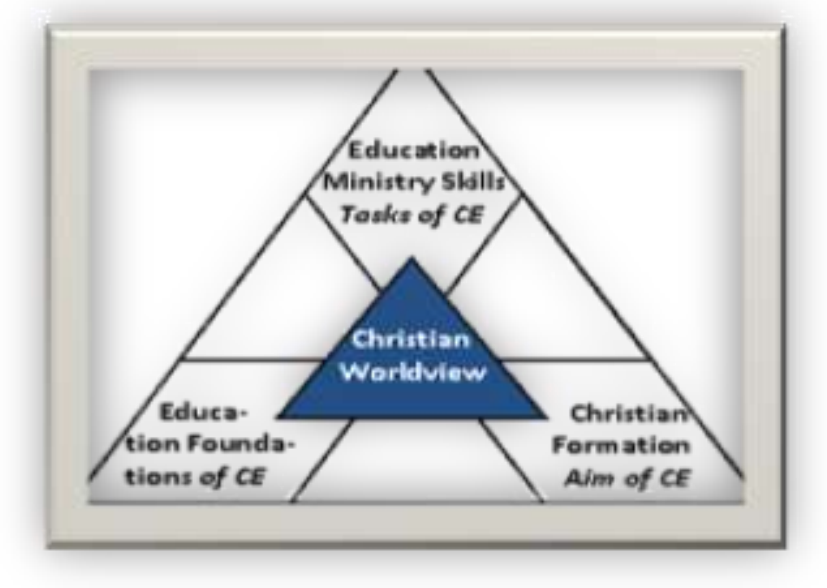

(Figure 5)

In Christian Education, our understanding is the fact that as Christians, the following of Jesus Christ of Nazareth is good news for humankind. It is the exceptional self-esteem of humans to be able to speak out individually with God, a relationship which can go beyond all outward appearance of human defenselessness, even ageing and death. Christian education therefore takes the weight off our feet within the main stream of Christian thoughts about God and humankind, seeking to provide the widest collection of Christian tradition in the UK and beyond. It tries to encourage and teach from an open and comprehensive approach to human acquaintances and thoughtfulness. (Creed, 2007)

Christian education indicates the progression of human prospective, through time and into infinity. The actualization of this prospective is what Christian Education comprehends as learning, both the transactional learning of the child and the transformative learning of the adult, together with the training outcome on each of the circumstance of time and place. Learning of this sort leaves the learner open to change in some way, becoming something other than previously. This is a Christian philosophy of education, communicating what education in its sincerely and most commanding sense is really about. (Creed, 2007)

Another way to express Christian education is considering what education put into the crucial circumstance of the creation of human beings in the representation of God, anticipated for relationship with Him and to be stewards of the creation. Education brings out human nature in the best possibility to achieve total human fulfillment to the glory of God and the good of all. In this sense all education is basically religious for it is grounded in the nature of humanity and its function. It is truly learning what is to be discovered about one's self, others around us, the world and life. As far as Christians consider that all these originate in and are 
sustained by a genuine, loving significant power, discovered in the person, teaching, life and new life of Jesus of Nazareth and is seen in the activity and indwelling of His Spirit today, all learning is religious. Science, technology, humanities, languages, arts and crafts and manifests all aspects of this Creative power. Christian Education understands religious learning to be developmental, preferably making progress from the mode of the dependent child to the mode of the independent adult, from the buildup of fragmented information to the achievement of an all-encompassing life-view. It is work which is constantly in progress and never definitively finalized. (Creed, 2007)

Most importantly, Christian education can also be understood as education into Christianity, just as science education might be seen as education in the sciences. Such explanation would involve the development, nurture and upbringing projected to lead a young person confessing the Christian faith. Such development would include teaching and learning about that faith and understanding something of its relationship to the rest of life. Christian education of this sort might join in varying ways with traditions of catechesis, evangelization or conversion. This understanding of Christian education is important for families that practice Christianity and communities as well as persons, and would take place within the broader values of Christian education described above. It might also be said that this kind of Christian education may provide the inspiration for a Christian approach to education generally. One who admits the Christian faith would want to comprehend the whole of his life as important for that faith. (Creed, 2007)

Christian education is definitely an education about Christianity. As far as this is one of the basics referred to above within education into Christianity such a vision could be seen as a narrower account of Christian education. However, it is not restricted to that, for education about Christianity is significant for nonChristians too in helping them to be aware of what Christianity is, how it has arisen and grow in history, and what its impact is on the humanity, communities and individuals. It can be seen then, that Christian education is a profound and complex term, where its different meanings and prominence extend beyond with each other. However, they are all grounded in a fundamental Christian theology, which interprets human life and Endeavour within the reality of God. In this common sense, all Christian education is potentially transformative of human life for it involves some kind of encounter with God either directly or indirectly through His creation. Comparable claims might be made by other religions for education. (Creed, 2007)

In an ideal world there should be a vigorous triangular affiliation between three role-players, the parents, the church and the school. While the parents are the crucial role-players (Deut. 6:7-9), this triangular relationship lay down a responsible arrangement as follows: (Woloch et al., 1974)

a. Church: The Church preaches Biblical doctrine and truth, which forms the theological foundation of the school and the family. They give confidence and direct parents, from Scripture, to take up their Biblical responsibility to educate and raise their children in the fear of the Lord. At its heart Christianity is a teaching religion Jesus Christ is referred to as the Teacher (John 3:2), the Holy Spirit's ministry includes teaching (John 14:26) and the Great Commission includes "teaching them to observe all things I have commanded you" (Mathew. 28:20). Christianity and the Church have always supported education. (Woloch et al., 1974)

b. Parents: The parents are the primary role players in the child's education as well as their upbringing, discipline and nurturing the fear of the Lord in their heart. They support their children going to Church, heeding the Word of the Lord as well as in getting education. (Woloch et al., 1974)

c. School: The school provides additional information about on the Biblical Worldview, looking at all areas of life, including from mathematics, to the sciences, to the languages and the arts from a Biblical Christian perspective. This is to prepare the Christian child to take authority for Christ and His Kingdom. It's an extension of the parent's mandate to "train up a child in the way he should go and when he or she is old they will not depart from it" (Prov. 22:6) and the Church's permission to "make disciples of all nations" (Math. 28:19).

All of the above three key role players make obligatory to one another and eliminate the mixed communication between the values of the Church and home been put against the secular humanist values of the public school. They mutually support godly discipline and therefore reduce delinquency and increase Christ-like character. Religious discipline allows for superior education, hence better academic achievements. It is important that parents be the main councils of schools to keep responsibility to the utmost level. All above three are subject to the Word of God. (Woloch et al., 1974)

\subsection{Benefits And Purpose Of Christian Education}

A Christian education is an investment. If you have the opportunity to provide Christian education for your children, you are investing in your children and their future for sure. It's never a wasted effort or wasted time. Both you and your children will reap the benefits in no time. If you eliminate all of the negative influences, Christian schooling will make an attractive option. Some say Christian schools cover children from the genuine world. How truthful is that statement? (Livingstone, 1997) 
Ok let assume that Christian schools actually cover children from the genuine world isn't that a wonderful idea? You may want to ask and know why? First and foremost one of the primary aims of the Christian School is to expand sensitive hearts. That can be achieved by working through issues and negative influences with students in a practical and biblically based environment. Christian schools strive to develop hearts that confront or copy the influences of things like humanism, evolution, dishonesty, and greediness, influence that are basically promoted in some state schools. Even ignoring all the positive influences that the Christian school make available or merely removing the unquestioned negative influences makes it an attractive, gorgeous and striking alternative for everyone. (Livingstone, 1997)

Parents who know that one of their primary responsibilities is to monitor the input there children receive in schooling environment and how that input that they have receive curves their perception of God and His world should consider enrolling their children in a Christian school or schools that offer Christian Religious Education as part of their curriculum. Most parents make an effort to protect their children at home by monitoring the books they read, the television programs they watch, the websites they surf, and the friends they keep outside their homes. Christian schools confirm the significance of this parental responsibility and the reasonably length at which the school goes to actively continue the work parents do. (Livingstone, 1997)

The genuine world is the one formed by God in which all things hold together by the supremacy of His Word. Only an education which recognizes the power of God over the dealings of men can be considered an education about the genuine world. To the degree that some state schools fall short to recognize God and give Him His due place, they are protecting children from the truth. Therefore, in actual reality, some schools who do not make provision for Christian Religious Education are the ones which protect children from the genuine and actual world, not Christian schools or schools with Christian Religious Education curriculum. (Livingstone, 1997)

The Christian school works somewhat like a greenhouse which is designed to provide optimum conditions for growth while a plant is young. Students are protected and carefully disciplined to help them mature properly. Even non Christian that also know the importance of Christian Religious Education and add it as part of their curriculum sees a difference in their students behavior because they are well disciplined. When the time comes for them to be transferred into a more antagonistic environment, they are more likely to tolerate difficulties, overcome problems and continue to thrive because they have been nurtured well and has developed a sensitive heart. (Livingstone, 1997)

These schools help to provide support and shorten the duty of Christian home and churches by reinforcing the same values and beliefs. The Christian school that provide Christian education makes the very difficult job of parenting a little bit easier by removing a major source of unquestioned negative influences from a child's life. (Livingstone, 1997)

Christian schools regularly talk about humanism, evolution, and other concepts enthusiastically accepted by mainstream society, but they do so from a Christian point of view. All of the problems which are part of a sinful world are also carefully discussed. They thrash out clarification based upon Biblical ethics. The school without Christian education teachings ignores the Christian view or presents it as only one alternative from among many. Meaning, pupils cannot be lead rightfully into making the right verdicts. (Livingstone, 1997)

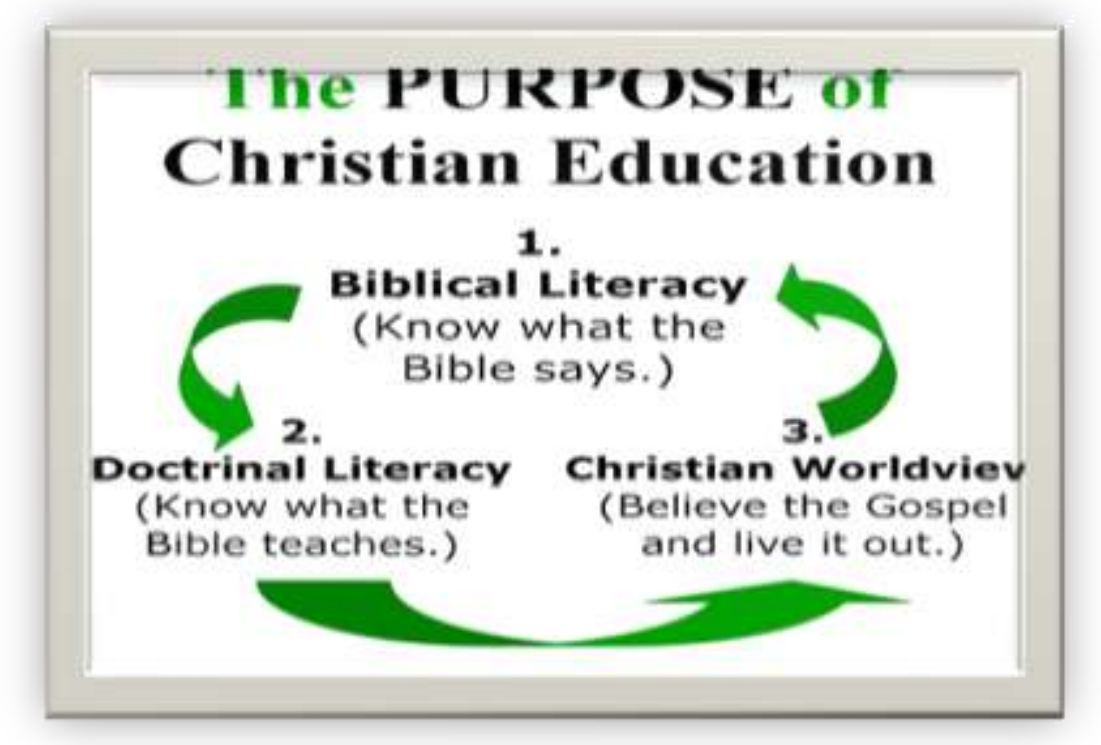

(Figure 7) 


\subsection{The Need For Christian Perspectives Today}

Education appears today to be in a constant changing state. At the same time this may reflect liveliness and fortitude to develop, it could also signify an extent of lack of direction and constancy. (Keast, 2008) In this situation, Christian perspectives may offer means of classifying main concern and improvements for education policy makers in the following areas:

- The scenery and reason of religious education

- Early Years Education

- School structures and choice

- Syllabus and ethos

- Collective worship

- Religious Education

- Achievement and accountability in schools

- Qualifications

- Further Education

- Higher education

\subsection{The General Objective Of Cristian Education}

In general, below are some primary objectives of Christian education God-centered Living: this includes the understanding of God's everlasting purpose, His means of carrying them out, and His revelation to man, understanding the nature of sin and its effects on human beings, and of salvation and its consequences, understanding and aspiration for God-oriented living as evidence of appreciation for salvation as well as appreciating the Christian's relation to creation.

Self-understanding and Development: this involves attainment of the skills of communication, (speech, reading, writing, number, intellectual inquisitiveness), understanding of one's own capacities and limitations and how they may be used to the highest level to serve man's purposes before God, understanding of the proper care and development of human resources (health, recreation, etc.), improvement of higher interests and appreciations (art, music, literature, esthetic and leisure time pursuits), development and conscious direction of attitudes and habits appropriate to the man of God as well as guidelines of moral and ethical behavior consciously related to God's revealed guidelines.

Establishment of Responsible Civic and Social Behavior: this includes development of attitudes and behavior patterns toward others consistent with Christian ethics, understanding of the forces and influences within and without which obstruct the development and application of wholesome Christian attitudes, willingness to assume responsibility for wholesome relationships with others (at home, in school, in recreation, in governmental activities), in social relationships, knowledge and understandings of the information and facts necessary for proper perspective in the solution of problems.

Vocational and Occupational Effectiveness: This includes understanding of the purpose of work in God's plan, understanding of the fields of work open to the Christian understanding of one's own capacities and aptitudes for particular fields of service, appreciation of the work and services of others.

\subsection{Various Aids To Christian Education}

\section{Chapter}

In gratifying their learning responsibilities, Christian Schools are enthusiastic to utilize all appropriate aids, they are anxious particularly about those which are her very own. First and foremost the first thing to do is to give catechetical instruction, which enlightens and make their faith more stronger, nourishes life according to the spirit of Christ, leads to intellectual and dynamic involvement in the liturgical mystery and gives inspiration for apostolic activity. Christian Education value extremely and seeks to break through and ennoble with her own spirit also other aids which fit in to the overall heritage of man and which are of great influence in forming souls and molding students, such as the media of communication, different assemblies for intellectual and physical progression, youth associations, and, in particular, schools..

\subsection{Importance Of Schooling}

Schooling over the years has been one of the major educational instruments with high level of importance. It been designed specifically to develop intellectual faculties but it advantage does not really ends there, it has gone further to form the capacity to judge rightly and to hand on the enriching inheritance of preceding generations. The process of schooling has fostered a sense of value for children and learners in general and also prepare students for professional life. Between student of different endowments and backgrounds it encourages friendly relations and fosters a spirit of reciprocated understanding and it establishes as it were a center whose work and progress must be collective together by families, teachers, associations of 
various types that promotes cultural, municipal, and religious life, as well as by civil society and the whole human community.

Schooling is beautiful indeed no doubt and of huge importance is the profession of all those who aid and support parents in fulfilling their job roles and who as representatives of the human community to successfully undertake the task of education and teaching in schools. This profession demands special qualities of intelligence and a heart that is carefully prepared with continuing willingness to renew and to acclimatize in a learning environment.

\subsection{Moral And Religious Education In Schools}

The basis of education is not just to learn science, social science or art anymore or simply to become a professional. We all should strive to make sure that our students learn some good sense of moral along with their normal education. Morals and ethics are what you get from allowing your child to participate in Christian religious education or any other religious educational subjects. Schools must present their own special affection for religious education. The teachers, assistant teachers and head teachers should first have a positive attitude towards religious education so that their encouragement can be passed on to the pupils and other generation coming into the educational setting. This is achievable by the witness of the lives of those who educate and direct these children, by the apostolic action of their fellow students, but especially by the ministry of priests and laymen who give them the doctrine of salvation in a way suited to their age and circumstances and provide spiritual aid in every way the times that conditions allow.

The school should have a responsibility to remind parents of the duty that is theirs to arrange and even demand that their children be able to enjoy these aids and advance in their Christian formation to a degree that goes alongside each other for their development in secular subjects. Therefore the Schools should take pride in those civil authorities and societies which, bearing in mind the pluralism of modern society and valuing religious autonomy, serve as a lending hand to families so that their children's education can be imparted in all homes according to the individual moral and religious ideology of the families.

\subsection{Catholic Schools}

Churches in general have made a great impart in children education for decades now. The contribution of the Church in the area of education is expressed in an extraordinary approach by the Catholic school. No less than other schools does the Catholic school pursue cultural goals and the human formation of youth. But its aim and objectives is to create for the school community a exceptional environment full of life by the Gospel spirit of freedom and charity, to facilitate youth growth according to the new creatures they were made through baptism as they develop their own personalities, and finally to order the whole of human culture to the news of salvation so that the understanding that the students suddenly and progressively obtain of the world, life and man is illumined by faith. So indeed the Catholic school, while it is open, as it must be, to the circumstances of the modern world, leads its students to encourage efficaciously the good of the earthly city and also prepares them for service in the spread of the Kingdom of God, so that by leading an very good apostolic life they become as it were, a very good and typical example in their human community.

Considering the view of the fact that, consequently, the Catholic school can be such an aid to the accomplishment of the mission of the People of God and to the nurturing of the dialogue between the Church and mankind, to the advantage of both, it maintains even in our present situation the greatest significance. Therefore this Holy Synod proclaims an additional thing that has already been taught in several documents of the superior, namely: the right of the Church generously to establish and to conduct schools of every type and level. And the committee calls to mind that the exercise of a right of this kind contributes in the maximum degree to the protection of autonomy of ethics, the privileges of parents, as well as to the betterment of traditions itself.

However, teachers should not fail to realize that the Catholic school depends upon them for almost all the achievement of its purpose and agendas. They should thus be extremely cautiously ready so that both in secular and religious knowledge they are prepared with appropriate training and experience and also with an academic skill that is keeping with the answers of the modern world. Catholic Schools been closely connected to aid organizations of one another and to their pupils and gifted with an apostolic spirit, a lot of teachers by their existence as much as by their order bear witness to Christ, the exceptional Teacher. Let them put effort as cohorts with parents and jointly with them in every stage of education give due thoughtfulness to the variation of sex and the appropriate ends to delightful fate consign to each sex in the family and in humanity. They should do all they can to inspire their pupils to do something for themselves and still after graduation to carry on assisting them with guidance, companionship and by establishing extraordinary associations permeated with the proper fortitude of the Church. The effort of these teachers, this holy synod declares, is in the factual logic of the word an apostolate most appropriate to and essential for our era and at once a right service presented to humanity. The committees also ring a bell to Catholic parents of the responsibility and obligation of entrusting 
their children to Catholic schools wherever and whenever it is achievable and of sustaining these schools to the paramount of their capacity and combine forces with them for the training of their children.

\subsection{The Use Of Bible In Christian Education}

The study of Christianity is centered in the bible, according to a renowned pioneer educationalist (Iris Cully). It begins from the life of the Christian community itself. The church discovers its genesis and distinctiveness in a story, "the account of God's care and love is made known in his creation and liberation through the people of Israel and through the birth, existence, death, and restoration of Jesus Christ" The Bible refers to one of two directly linked religious texts vital to Judaism and Christianity the Hebrew or Christian holy scriptures respectively. Using the holy bible to educate Christian children is a significant and serious aspect of early education. This is not just because the bible education is designed for only children who are valued in encouraging their spiritual well-being, but because they are after all also very important as moral instructions.

Am sure you are aware that children don't hold completely advanced religious sense already. They have to be taught for them to develop with such senses. For children, God is perceived more as a fantasy friend than the creator of the entire world. For that reason u can't suppose them to recognize the subtleness of a message on the Bible. It has to be cautiously customized to their point of indulgent or they won't grapple whatever thing from of it.

A comprehensive premium Bible teaching planned for children needs to take a number of cues from common children's activity. The activity diligence spends millions upon millions of dollars coming up with kid's entertainment each year, and they have learned a phenomenon or two in relation to it. That doesn't mean that Bible education in support of children needs to maintain the careless principles with the function of Hollywood glorifies, but it means with the rationale of the control to be child friendly. Using puppets, knowledgeable animations, plain language with the idea of children like, and amusing jokes is a terrific way to deliver the Bible more sociable in support of adolescent readers. Make it entertaining in support of them and they will stay with it in support of an existing period.

The furthermost Bible education in support of children in fact stresses the subject of faithfulness and faith as well as exciting activity. Think on the order of the children's Bible stories with the aim of are for the most part commonly taught. Noah and the Ark are next to the top of the inventory, and Moses' exodus from the Egyptians is purely slightly little further down. Both of these deals with extraordinary themes: Floods, the anger of God and animals in support of friendless, and plagues, traveling in the desert, and counterfeit idols in the other. They inspire the judgment of childish audiences, which is an impressive way to make them concerned in the Bible.

\subsection{Bible Courses}

Schools precisely oblige almost all students to study a Shakespeare play at some point still they generally pay no attention to the Bible even though it has been greatly more significant than all of Shakespeare's plays together. No book has been as influential in the history of the world as the Bible. Certainly, for millions of Americans the Bible carries on to be the starting place of their deepest sincerity and commitments. If any book merits inclusion in the curriculum, it is the Bible.

Bible courses may take a variety of structure

- The Bible as Literature: learners can learn the Bible in terms of visual categories, as a collected works of narratives, stories, and poetry, exploring its language, symbolism, image, and archetype.

- The Bible in Literature. Learners might learn the ways in which afterward writers have used Biblical stories, language, symbols, ornamentation and archetypes.

- The Bible as History. Learners might study the Bible for the light it throws on antique history. The holy history originated in the Bible is quite different from the secular history of academic historians. What we can learn about history from the Bible depends on how we translate it and the criterion we use to assess the soundness of historical claims both matters of substantial argument.

- The Bible in History. Learners can learn how people of different religious ethnicity have understood the Bible, and how it has prejudiced our social and cultural institutions, our faith and values. Though the Bible is as significant as literature or history, its immense power has been on later literature and history, its primary significance has clearly been as a religious text, as Scripture; certainly, this is the resource of the Bible's mythical and historical significance. To read the Bible simply as literature or history would be a little like reading poetry as if it were no more than prose it would be to miss an aspect of meaning that is in Scripture. It is through the Biblical description of the Creation, God's covenant with Abraham, the moral extremism of the Hebrew Prophets, Jesus' philosophy of love and the coming Kingdom of God, and his death and restoration, that Jews and Christians have acquired their understanding of authenticity. Not to be pleased 
about the religious roots of development with all of the theological, ethical, communal, political, and logical branches that are nourished by them, is to stay amateurish. And so we add a fifth opportunity.

- The Bible as Scripture. Learners may deem the fundamental religious claims made in the Bible, how a variety of religious customs have interpreted those claims, and how those claims have inclined our history and culture. Of course, to learn the Bible as Scripture, as we suggest it, is not a subject of reading it devotionally, but learning about how the Bible has been understood as Scripture within a variety of different society.

\subsection{The Major Issues}

Whatever the case, we must tackle several major issues if we are to assume a unbiased and educational approach.

- Who's Bible? Is there a single bible? Certainly not. In fact, there is a Jewish Bible and various Christian Bibles Catholic, Protestant, and Orthodox each unruffled of different books, arranged in diverse orders. These differences are significant. Unnecessary to say, it makes a huge deal of difference if the New Testament is a branch of the Bible. Of course, Judaism is a religion of the Talmud as well as of the Hebrew Bible. Even the understanding of books is of significance: for example, the Hebrew Bible ends with Cyrus's admonition to the Jews in second Chronicles to go to Jerusalem, the Christian Old Testament ends with Malachi's prophecy of the coming of the Messiah. To adopt any particular Bible will suggest to these young learners that it is normative, the best Bible. It will be the Bible of some pupils and will be foreign to others. Arguably, public schools should use an inclusive Biblical sourcebook that is different from but includes the key texts of each of these Bibles though such a textbook would not itself be a Bible. If a single Bible is to be used, it must, without doubt, be the most comprehensive; therefore, teachers should tell again students at various essential points in the course that their Bible is different from other Bibles and the significance of this. Students should, of course, study how the different Bibles came about.

- Whose translation? Who translated the bible? In what and how many languages? Traditions and denominations often have their own official translations. Whatever its mythical merits or religious authority for conservative Protestants, the language of the King James Bible is difficult it was archaic even when it was translated in the 17th century and a modern translation is essential. Many scholars prefer the New Revised Standard Version, but many conservatives object to its use of gender-inclusive language. What is important educationally is for students to understand these controversies, read from several translations, and reflect on their theological importance.

- Whose interpretation? Horace Mann and his successors in the common school movement of the 19th century argued that the King James Bible should be read in school without comment or theological gloss as a way of maintaining doctrinal neutrality. Mann's approach continues to have its advocates. The manual for the widely used curriculum of the National Council on Bible Curriculum in Public Schools rightly states that study of the Bible must be free of sectarian biases, but it takes this to mean that the King James Bible (which it recommends) should be read without commentary: "Study about the Bible should center on the biblical text itself rather than the extraneous material and theories which might express a particular theological position rather than the historical presentation found in the Bible." Indeed, this approach is "consistent with the teaching found within the Bible. Of course, this was and is a peculiarly Protestant indeed, conservative Protestant approach to the Protestant King James Bible. Jews have always read the Hebrew Bible through rabbinic clarification, and Catholics have always insisted that the Catholic Bible requires the reliable explanation of the church. Why? Because the meaning of the Bible isn't clear; it requires explanation. That is, just to read the Bible doesn't avoid sectarian prejudice; rather, it adopts a particular sectarian approach. But couldn't one argue that reading the Bible without commentary is not simply a Protestant approach; it is a secular approach and, as such, is appropriate for public schools? There are two problems with this. First, the Establishment Clause requires neutrality between religion and non religion as well as neutrality among religions; that is, schools can't privilege a secular over a religious reading of the Bible any more than they can privilege a particular religious interpretation. The other problem is that any good secular reading of the Bible requires the use of contemporary chronological and fictional condemnation that is, it requires academic clarification to make good judgment of the manuscript or passage.

Beginning in the 19th century the resources of modern secular scholarship in history, philology, and archaeology were brought to bear in developing a new understanding of Biblical texts. For example, scholars argued that the Torah, or Pentateuch, was not the work of Moses but the redaction of at least four quite different sources. Biblical texts such as the Noah narrative were variations on non-biblical stories common in the ancient Near East. The Gospels were written 30 to 90 years after Jesus' death by men who did not know him but drew on various sources to develop somewhat different and conflicting portraits of him. In our century, liberal Jewish and Christian theologians have drawn heavily on this scholarship to interpret the Bible and rethink their traditions, while conservative Christians and Orthodox Jews have typically reaffirmed that the Bible is inerrant 
at least in its essential teachings. It is important to note that there is a difference between holding the Bible to be inerrant, and holding that it should be read literally; theologians have often held, for example, that the true or intended meaning of a passage is allegorical, or metaphorical, and requires interpretation. And then, of course, there are the fundamental differences between Jewish and Christian readings of Scripture. Does the "suffering servant" passage in Isaiah 53 refer to Jesus or to Israel? Is the serpent of Genesis 3 Satan? Do we read the Hebrew Bible, the Christian Old Testament, in terms of the New Testament?

Teachers must maintain some sense of tension between letting the text like any primary source speak for itself and drawing on the resources of different secular and religious interpretative traditions for understanding it. If we are to educate students about the Bible, if it is to be studied neutrally, we must expose students to the major different ways of reading the Bible in our religious and scholarly traditions. To do this effectively requires the use of secondary sources that deal with various approaches to the Bible.

- Whose selections? Individuals often argue that the Bible can be quoted in support of any cause. This is an exaggeration, but there is a point to it. Some biblical texts were quoted by slave holders, others by abolitionists. Different religious traditions have valued (and sometimes denigrated) different portions of the Bible. Students should read enough of the Bible to acquire some sense of its recurring themes, but if they can't read the entire Bible and it's unlikely that they can, teachers must be cautious in selecting the parts they consign.

- The Bible and history. One of the problems with just reading the Bible is that this wrenches it out of its historical context, throwing students on their own, typically meager, resources for making sense of texts written in different languages and cultures. Students should learn about the Bible in the context of the ancient Near East, in part to understand what was common to the times and what was distinctive about the Bible. Even more important, students must study the Bible in the context of the various major historical interpretative traditions that have shaped its meaning as Scripture. Indeed, because the Bible has been the most influential of all books, students should learn something about its historical influence on a wide variety of cultural institutions and controversies and on people's most basic beliefs and standards at this time and at this present.

- Required Bible courses? Given its significance and authority, schools should require all students to study the Bible in some depth, but we should do not favor required Bible courses as a way of getting to this end, in part because this came a slightly too close to privileging the Jewish and Christian customs. Educators should incorporate some study of the Bible into suitable world history and literature courses at contextually appropriate places though, as we've argued, likely enclosure doesn't get us very far. The ideal, once again, is to incorporate the Bible into a religion course in which it would be studied with other sacred scriptures. When the Wake County schools in Raleigh, North Carolina, began offering high school Bible courses several years ago, they required that each of the high schools also offer world religions courses. We find considerable merit in elective Bible courses but believe they should be supplemented in the syllabus by courses in other world religions that give all students the chance to learn their own way of life and put across to them the common sense that their religions are in use fatally.

\subsection{History Of The Bible}

The history of the Bible starts with a phenomenal account of history. It's not one book like most of us will assume. It's a very old anthology of writings, comprised of 66 separate books, written over just about 1,600 years, by at least 40 distinct authors. The Old Testament contains 39 books written from roughly 1500 to 400 BC, and the New Testament contains 27 books written from around 40 to 90 AD. The Jewish Bible (Tanakh) is the same as the Christian Old Testament, with the exception of for its book collection. The imaginative Old Testament was written primarily in Hebrew, with some Aramaic, while the unique New Testament was written in common Greek. (Wikipedia, 2010)

The history of the Bible begins with the Jewish Scriptures. The chronological record of the Jews was written down on leather scrolls and tablets over centuries, and the authors included kings, shepherds, prophets and other leaders. The first five books are called the Law, which were written and edited primarily by Moses in the early 1400's BC. Thereafter, other scriptural texts were written and collected by the Jewish people during the next 1,000 years. About 450 BC, the Law and the other Jewish Scriptures were prearranged by councils of rabbis (Jewish teachers), who then recognized the complete set as the inspired and sacred authority of God. At some time during this period, the books of the Hebrew Bible were arranged by topic, including The Law (Torah), the Prophets (Nebiim), and the Writings (Ketubim). The first letters of these Hebrew words T, N and K form the name of the Hebrew Bible the Tanakh. (Halley, 2000)

Beginning as early as $250 \mathrm{BC}$, the Hebrew Bible was translated into Greek by Jewish scholars in Alexandria, Egypt. This translation became known as the 'Septuagint' meaning 70 and referring to the tradition that 70 (probably 72) men comprised the translation team. It was during this process that the order of the books was changed to the order we have in today's Bible. 
Although the Jewish Scriptures were copied by hand, they were extremely accurate copy to copy. The Jews had a phenomenal system of scribes, who developed intricate and ritualistic methods for counting letters, words and paragraphs to insure that no copying errors were made. These scribes dedicated their entire lives to preserving the accuracy of the holy books. A single copy error would require the immediate destruction of the entire scroll. In fact, Jewish scribal tradition was maintained until the invention of the printing press in the mid-1400's AD. As far as manuscript accuracy, the recent discovery of the Dead Sea Scrolls has confirmed the remarkable reliability of this scribal system over thousands of years. (Zondervan Handbook, 1999; Wikipedia, 2010)

After approximately 400 years of scriptural silence, Jesus arrived on the scene in about $4 \mathrm{BC}$. Throughout his teaching, Jesus often quotes the Old Testament, declaring that he did not come to destroy the Jewish Scriptures, but to fulfill them. In the Book of Luke, Jesus proclaims to his disciples, "all things must be fulfilled which were written in the Law of Moses and the Prophets and the Psalms concerning Me." (Luke 24:44, New King James Version)

Starting in about $40 \mathrm{AD}$ and continuing to about $90 \mathrm{AD}$, the eye-witnesses to the life of Jesus, including Matthew, Mark, Luke, John, Paul, James, Peter and Jude, wrote the Gospels, letters and books that became the Bible's New Testament. These authors quote from 31 books of the Old Testament, and widely circulate their material so that by about $150 \mathrm{AD}$, early Christians were referring to the entire set of writings as the "New Covenant." During the 200s AD, the original writings were translated from Greek into Latin, Coptic (Egypt) and Syriac (Syria), and widely disseminated as "inspired scripture" throughout the Roman Empire and beyond (Bruce, 1960). In $397 \mathrm{AD}$, in an effort to protect the scriptures from various heresies and offshoot religious movements, the current 27 books of the New Testament were formally and finally confirmed and canonized in the Synod of Carthage. (Bruce, 1960; Wikipedia, 2010)

\section{Chapter}

In this chapter, my aim is to formulate a curriculum that will help a primary school student develop a thorough knowledge and understanding of Christian Religious Education. It is very important to allow student learn from the scratch in other not to miss out on anything. This can be used as a hand or texts book whichever way. Each topic can be taught ones in a week. Students should endeavor to study the moral lessons derived from each topic answer the questions on each topic which should be submitted the following week. This home work should always be marked and assessed by teachers and correction given in the next class to eliminate any draw back in lessons. With this, students can achieve some positive experience from the course. However, teachers of different grades and classes should bear in mind that the teaching in class rooms and home work is not all that matters in putting the word of God into practice. The behavior of a class teacher can also influence the behavior of the students. If a teacher comes to class half naked and the head teacher does nothing about it the students automatically thinks that the dress code is a normal working cloth. That student will eventually enter into the mainstream society and will be no different from a child who did not even learn Christian religious education. So what the teacher, parents and society do at large in the presence of these children always have an influence on them. This curriculum should therefore work in accordance with physical moral discipline. Below is a curriculum that will assist a child to get started in life and school.

\section{Theme 1: God and the creation of the world TOPIC 1: WHO IS GOD?}




\section{UNIT 1: WHO IS GOD?}

God is seen as supernatural (i.e. being above or beyond what is natural), a creator and the overseer of the universe.

In Genesis God is the Creator, In Exodus, God is the Redeemer. In Leviticus, God is our Sanctification, In Deuteronomy, God is our teacher and in Joshua, God is the mighty conqueror.

\section{GOD IS UNIQUELY ONE}

We as children of God must have in mind that we are governed by the revelation that God is uniquely one. The Bible tells us that God is one.

\section{GOD EXIT IN ALL THREE}

\section{God the Father}

Undoubtedly the Father is God. In various places the New Testament speaks of God the Father. See, for example, 1 Peter $1: 2$ and Ephesians 1:17.

\section{God the Son}

The Son also is God. Hebrews 1:8 says, "But unto the Son he saith, Thy throne, O God...." Here the Son is addressed as God. John 1:1 says, "In

In the bible, God has promised us his children love, care and forgiveness. God is holy, pure and righteous. God has promised to keep all of his promises only if we as his children can meet all his conditions. That is obeying him in all situations that we find our self. "He said, Believe on the Lord Jesus Christ, and thou shall be saved".

His condition is to believe. His promise to us is that we will be saved. God has not wished any of his children to be perished, but he wishes that all should come to repentance. John 3 verse 16 says "For God so loved the world that he gave his only begotten son, that whosoever believeth in him, should not perish, but have everlasting life.

\section{UNIT 2: CONCEPTIONS OF GOD-Holy} Characteristics

Those who have studied about God and religious faith have found different characteristics of the divine being of God. The most common among these are omniscience, omnipotence,

Omnipresence, omnibenevolence (perfect goodness), divine simplicity, and eternal and necessary existence. These attributes were all supported to varying degrees by those who studied the field early Jewish, Christian and Muslim religion.

Omniscience: God knows everything infinitely. "God possesses perfect knowledge and therefore is no need for him to learn

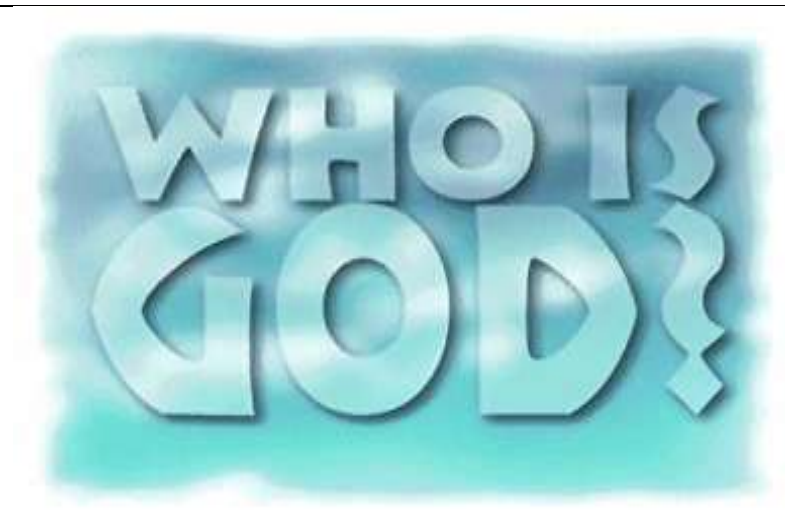

the beginning was the Word, and the Word was with God, and the Word was God." The Word certainly is Christ, the Son. Since the Word is God, the Son also is God. Furthermore, Romans 9:5 says, "Christ...who is over all, God blessed forever." I like this verse. Christ the Son is not only God; He is God over all.

3. God the Holy Spirit

In Acts 5:3-4 we see that the Spirit is God. In verse 3 Peter told Ananias that he had lied to the Holy Spirit, and in the next verse that he had lied to God. These verses equate the Holy Spirit with God.

The Father, the Son, and the Holy Spirit are God. How many Gods do we have? We have one. How can the Father, the Son, and the Holy Spirit all be God and yet there be only one God? The only answer we can give is, "I don't know."

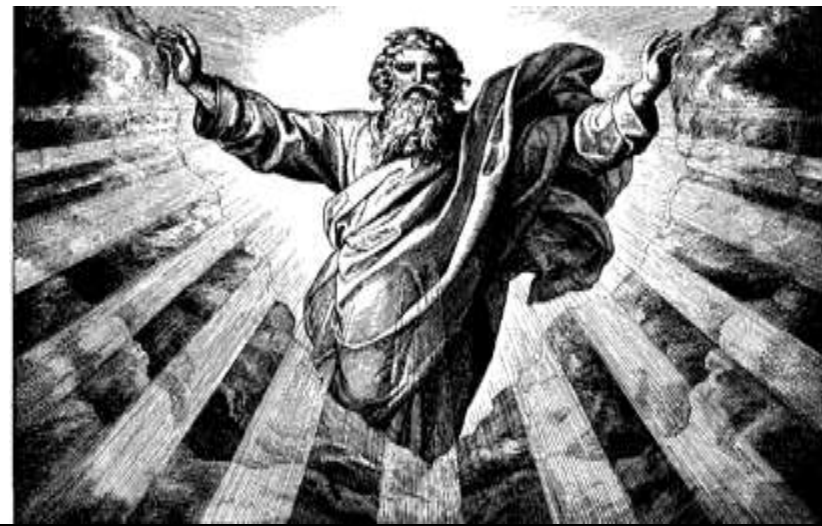

Omnipotence: God is seen as one who has unlimited power.

Faithfulness: Everything that God has pledge will come to fulfillment. His truthfulness guarantees this fact. He does not lie. What He has said in the Bible about Himself is factual. Jesus even said that $\mathrm{He}$ is the Truth.

Holiness: This is the attribute that sets God separately from all other created beings. It refers to His majesty and His wonderful moral wholesomeness. There is absolutely no sin or evil thought in God at all. His holiness is the definition of that which is pure and virtuous in the whole universe.

Sovereignty: This is "the attribute by which He rules His entire creation."

Wisdom: "Wisdom is the capacity to develop perfect ends and to accomplish these ends by the most wonderful means." In other words, God makes no error or fault. $\mathrm{He}$ is the Father who truthfully knows best, as Paul explains in Romans 11:33: "Oh, how great are God's riches and intelligence and knowledge! How unfeasible it is for us to understand His judgments and His ways!" 


\begin{tabular}{l}
\hline UNIT 3: NAMES OF GOD IN THE BIBLE. \\
EL: El means God. (Mighty, strong and \\
prominent) \\
ElOHIM: ELOHIM means God. (God as \\
creator, preserver, mighty and strong. \\
EL SHADDAI: God Almighty or God All \\
Sufficient. \\
ADONAI: ADONAI means Lord or Master \\
JEHOVAH: JEHOVAH means Lord. \\
JEHOVAH-JIREH: Means "The Lord will \\
Provide" \\
JEHOVAH-NISSI: Means "The Lord Our \\
Banner". \\
JEHOVAH-SHALOM: Means "The Lord Our \\
Peace". \\
JEHOVAH ELOHIM: Means "LORD God". \\
EMMANUEL: Means "God with us" \\
ALMIGHTY: Means Massive \\
ALPHA and OMEGA: The First and the Last, \\
The Beginning and the End.
\end{tabular}

UNIT 3: NAMES OF GOD IN THE BIBLE. EL: El means God. (Mighty, strong and prominent

creator, preserver, mighty and strong.

Sufficient

JEHOVAH: JEHOVAH means Lord.

Provide"

JEHOVAH-NISSI: Means "The Lord Our JEHOVAH-SHALOM: Means "The Lord Our Peace".

EMMANUEL: Means "God with us"

ALPHA and OMEGA: The
The Beginning and the End.

\author{
NAMES OF GOD IN NIGERIAN LANGUAGE \\ ISHAN: OSELEBUA \\ BINIS: OSANOBUA \\ YORUBAS: OLODUMARE OR OLUWA \\ IGBOS: CHINEKE \\ EFIK: ABASI \\ IJAWS: EGBESU \\ HAUSAS: UBANGIJI
}

\section{Moral Lessons}

We must serve God with all our hearts and soul so that we can have a good relationship with Him.

All the religions of the world believe in the existence of a Supreme Being who created the heaven and the earth.

\section{Questions}

Describe the condition of the earth before the creation of the world Who is God?

List five attributes of God

Write the names of God in four local languages

\section{TOPIC 2: GOD'S CREATION}

\section{UNIT 1: BIBLICAL ACCOUNT OF} CREATION (Genesis 1:1-25)

Creation is an act or causing the existence of something or a way of bringing or doing something new. Throughout the scriptures God is identified as the creator. He is the creator of the heaven and earth and the sea and all the things in them.

God is the Supreme Being who created all human beings. He created man in his own image: male and female, He created them and gave them authority over other creations.

\section{Biblical Sequential Account of Creation.}

The biblical account of the story of the creation is not history as such. It is regarded as a myth. Myth is pre-historic attempts by man to give answers to most difficult questions posed by both the supernatural in creation.

Genesis chapter 1 and 2 contains the creation story. The bible told us that all things were created from nothing and by the words and things were as He said them by command "let there be..." And they were so.

All things were created in six days and God rested on the seventh day.

\section{The Dignity of Man in God's Creation}

The dignity of man can be seen in the fact that God created man in His own image. The time came when the lord formed a man's body from the dust of the earth and breathed into his nostrils, the breath of life. And man became a living soul.

And God said, "it is not good for man to be alone, I will make a companion for him, a helper suited to his needs. So out of the ground the lord God formed every beast of the field and every bird of the air, and brought them to the man to see what he would call them; and whatever man called every living creature, that was its name.

But still there was no proper helper for the man. Then God caused man sleep deep, and took one
Day One: Creation of Light (Genesis 1:1-5)

In the beginning God created the heaven and earth. The earth was dark, empty and shapeless and the spirit of God moved over the face of the waters. And God said "Let there be light and there was light."

And God saw that the light was good. He separated the light from the darkness. God called the light day and the darkness he called night.

Day Two: Creation of Heaven and Earth (Genesis 1:6-8) And god said "let there be firmament in the midst of the waters, and let it separate the water above it from the water below". And God called the firmament heaven.

Day Three: Creation of Land, Sea and Trees (Genesis 1:913)

And God said, "let the water under the heavens be gathered together into one place, and let the dry land appear". And it was so. God called the dry land Earth, and the water he called the Seas. And God looked at all what he has done and they were good. Then God said, "Let the earth put forth vegetation, plants yielding seed, and fruit trees bearing fruit in which is their seed, each according to its kind, upon the earth." And it was so.

And God had a look at all he had created and they were good.

Day Four: Creation of Sun, Moon and Stars (Genesis 1:1419)

And God said, "Let there be light in the firmament of the heaven to separate the day from the night, and let there be sign for the seasons, days and years and to shine upon the earth." And God saw that it was good. And God made two great lights, the greater light will rule the day and the lesser light to rule the night. He made the stars also. And God looked at what he had done and saw that they were beautiful in his eyes.

Day Five: Creation of Sea Animals and Birds (Genesis 1:2023)

And God said, "Let the waters bring forth swarms of living creatures, and let the birds fly above the earth across the firmament of the heaven." So God made giant sea monsters 
of his ribs and closed up the place from which he had removed it, and made the rib into a woman, brought her to the man (Adam).

When Adam woke up and saw her, he exclaimed, "She is part of my own bone and flesh. She shall be called woman because she was taken out of a man." With the creation of man and woman, this shows that both man and woman were created equal by God. People all over the world, both black and white are all equal before God because they were all made in the image of God.

Songs about creation

All things bright and beautiful

All creatures great and small

All things bright and wonderful, The lord God made them all

Moral Lessons

God is the supreme creator; we are all equal before God, because we were made in His image. God created other things in the universe for the comfort of man (human being)

\section{Ouestions}

Write out the opening verse of Genesis 1vs1.

What did God create on the $4^{\text {th }}$ day?

What did God make on the $6^{\text {th }}$ day?

State two reasons why God created human beings. and all the sea. He also made every kind of birds. And God looked at what He had done and saw that it was good. And God blessed them, saying, "Be fruitful and multiply and fill the waters in the seas and let the birds multiply on the earth."

Day Six: Creation of Other Animals and Man (Genesis 1: 26-31)

Then God said, "Let us make man in our own image, after our likeness, and let them have dominion over the fish of the sea, and over the birds of the air, and over the cattle, over all the earth, over every creeping things"

And God created Man in His Own Image, male and female, He created them. And God blessed them and said to them, "Be fruitful and multiply, and fill the earth and subdue it." God gave authority and control to man over all animals, birds, fish and all creeping things on earth.

\section{Day Seven: Day of Rest (Genesis 2:1-3)}

By the seventh day God had finished His work of creation, and so He rested. God blessed the seventh day and made it holy because on that day He rested from his work.

\section{UNIT 2: WHY GOD CREATED HUMAN BEINGS}

Human Beings the finest and highest of all His creation was made in His own very image. God made man from the dust of the earth and breathed into his nostrils the breath of life and man became a living being.

God created man so that man will have dominion over all the living things He has created on earth. God created man so that he may know Him, love Him, and serve Him here on earth and also live with Him forever in Heaven.

\section{TOPIC 3: HUMAN BEINGS SHARE IN GOD'S CREATIVE ACTIVITIES}

\section{UNIT 1: MEANING OF MARRIAGE}

(Genesis 2:22-25; Ephesians 5:21-31)

Marriage can be defined as the joining of man and woman for the purpose of living together as husband and wife, which becomes the foundation for a home and family. The Bible defines marriage as a divine institution, authorized and established by God in the Garden of Eden, Marriage brings into being the family unit.

\section{Origin of Marriage (Genesis 2:18-24)}

Marriage was instituted by God when He declared, "it is not good that man should be alone; I will make him a helper fit for him" So God formed a woman from the rib of Adam and brought her to him. When Adam saw the woman he said, "this is the bone of my bone and the flesh of my flesh, she shall be called woman because she was taken out of man. "This passage also emphasizes the truth that a man shall leave his father and mother and be joined to his wife and they shall become one flesh. This suggests that God's ideal is for a man to be the husband of one wife and for the marriage to be permanent. Therefore polygamy was not intended by God.

Man's first share in God's creative activities is in giving birth to children, this is called PROCREATION. By procreation through marriage, the human race is preserved. In Nigeria there are different forms of marriages which are recognized

UNIT 2: Functions of Marriage

The main basic function of marriage is for procreation in order to preserve the human race. Marriage is designed to form a permanent bond of union between man and woman,

\section{In law.}

There is Traditional marriage also called marriage by native law and custom. In different areas, there are different ceremonies and rules. But if these are carried out properly, in the traditional way, then the marriage is accepted as legal anywhere in Nigeria.

There is also marriage under the ordinance. This is not tradition. This is carried out in:

REGISTRY OFFICE

CHURCH

MOSQUE

Most people choose to be married in church or to have their traditional marriage blessed in church.

Any other form of marriage is unacceptable in the sight of God. The joining of man to man or woman to woman is not sanctioned by God, and so it is unacceptable. The act of homosexuality or lesbianism can lead to sexually transmitted diseases (STD), and therefore it should be avoided. 
that they might be helpful to each other. That they live together in love and confidence and enjoy great happiness. God created woman as a help mate for man by using the man's rib as a base thereby making her man's closest fleshly relative on earth, his own flesh (genesis 2:21)

Marriage is also to prevent promiscuity which may lead to sexually transmitted diseases (STD)

Marriage makes a man responsible in the society. When a man gets married he is respected and said to be a responsible family man. Marriage is for companionship between man and his wife. They are to love each other and grow old together.

UNIT 3: Things invented by man

Through the ages, man has been using his creative activities to develop the various natural resources at his disposal in his environment for the benefit of mankind. Man invented airplanes to fly in the air, tractors, cars etc.

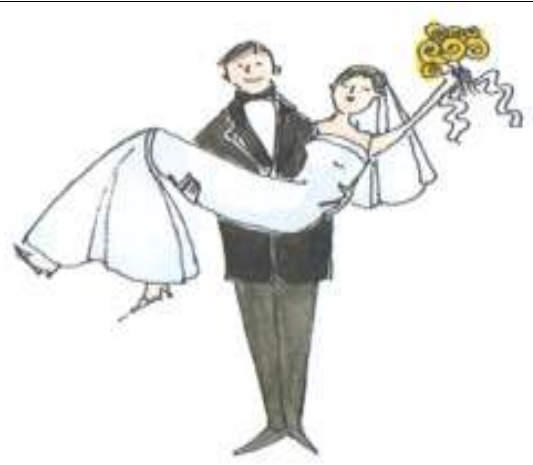

Moral lessons

The man and woman are to complement each other We should be more creative, so that we can contribute to the development of the earth

In other to procreate we should be properly married We must show gratitude to God for his mercies

\section{Questions}

Mention two ways which man can share in God's creative activities

Mention four things invented by man

What is marriage?

Give two reasons why man should not marry his fellow man.

\section{TOPIC 4: BIBLICAL ACCOUNT OF THE FIRST HUMAN DISOBEDIENCE (Genesis 3:1-9)} UNIT 1: Disobedience
Disobedience can be defined as rule breaking or refusal to
obey rules and regulations. Unwillingness to comply with
the guide of authority, especially refusal to follow God's will.

The first sin recorded in the bible is the sin of disobedience which occurred when Adam and Eve ate the forbidden fruit... When God created Adam, He put him in the Garden of Eden where all that he needed for comfort were provided. Two other trees were in the middle of the garden. One of the trees gave life, and the other gave power to know the difference between right and wrong.

God put the man in the Garden of Eden to take care of it and to look after it. Then God commanded him saying, "you may eat fruit from any tree in the garden except the fruit of the tree which is in the middle of the garden. You shall not eat neither shall you touch it, if you eat from it you will surely die"

The serpent was more cunning than any other animals that God had made. One day it came to the woman and asked. "Did God tell you not to eat fruit from any tree in the garden?" She answered, "God said we could eat fruit from any tree in the garden, except the one in the middle. He told us not to eat fruit from that tree or even touch it. If we do we die". The serpent said to the woman,

"You will not die for God knows that in

UNIT 2: Consequences of Adam and Eve's Disobedience (Genesis 3: 14-19)

The Consequences of Adam and Eve's sin are as follows:

Shame: They became ashamed of themselves. Before they sinned, they were naked but they were not ashamed, they moved about freely in the Garden of Eden. After eating the forbidden fruit, they became ashamed and sewed fig leaves together to cover their nakedness. In other wards sin brings about shame.
The day you eat of it your eyes will be opened, and you will be like God, knowing good and evil." So when the woman saw that the tree was good for food, and was pleasant to the eyes and a tree desirable to make one wise, she took of its fruit and ate. She also gave to her husband with her, and he ate. Then the eyes of both of them were opened, and they knew that they were naked, and they sewed fig leaves together and made themselves coverings.

When they heard the sound of God walking in the garden in the cool of the day, they hid themselves from the presence of God. When God called Adam and asked him where he was, he replied, "I heard the sound of thee in the garden, and I was afraid because I am naked, and I hid myself" God asked, "Who told you that you were naked? Have you eaten from the tree that I told you not to eat?" Adam replied, "The woman whom you gave me, she gave me of the tree and I ate". God said to the woman, "What is this that you have done? "The woman replied, the serpent deceived me and I ate"

UNIT 3: Learner's Disobedience

Learner's disobedience occurs when the learner breaks the school's code of conduct (rules and regulations).

Every school has its own code of conduct whether government owned or private schools which are given to new intakes (pupils) upon their arrival. These rules and regulations differ from school to school. They are meant to guide the conduct of the learners while in school. Learner's disobedience is not treated lightly. When a learner disobeys the rules and regulations, he or she is severely punished by the school authority. The punishment received varies, depending on the gravity of the offence committed by the learner.

Note: The teacher is to discuss this topic extensively in class. Students to contribute to the discussion by giving examples of offences and types of punishments. 
Fear: Before the sin of disobedience, they were not afraid of God. They used to walk and talk with God in the Garden of Eden. But after their sin of disobedience, they became afraid and hid themselves from God.

Separation from God: The friendship between them and God was cut-off. They were separated from God.

Loss of paradise: As a result of their sin, God drove them away from the Garden of Eden (paradise) where everything they needed to make life easy for them was provided. They went into the harsh world where Adam will have to struggle to exact a living from the cursed soil.

The serpent and Eve were also cursed. Eve will bear children in severe pain and suffering. While the serpent will crawl on its belly and eat sand. Sin breaks our relationship with God. While God protects and guides those who do His will, he punishes those who refuse to obey Him.

\section{Guidelines:}

Types of offences e.g. When the learner fails to put on the specified school uniforms or fails to dress properly, lateness to school, fighting, loitering during school hours, speaking vernacular in class, etc.

\section{Punishment:}

Suspension for one or two weeks, clearing of school field, etc.

\section{Moral Lessons}

We must not be disobedient

We must pray to God to help us overcome temptations.

\section{Questions}

The sin committed by Adam and Eve is called Explain the term disobedience

\section{Conclusion}

In conclusion to this study, I will say religious education from all angle and from all area of research has shown without any doubt that its significance on children and society cannot be ignored. Religious Education has prove to make available openings for spiritual expansion in the course of helping students to think about and act in response to questions of meaning and function in life, and questions about the scenery of morals in human society; to consider and react to the exquisiteness of life and the arts; to have the chance to experience fear and wonder and, through times of silent manifestation, to experience stillness and moral development through helping pupils to consider and respond to areas of morality using their knowledge and understanding of religious and ethical teaching.

This has helped students to make articulate and knowledgeable decision on religious and moral issues; collective progress through helping pupils to develop their sense of character and belonging, preparing them for life as citizens in a multi-cultural society; cultural growth through nurturing pupils' consciousness and understanding of variety of beliefs, practices and values in their own society and in the entire world at large. Students investigate issues within and between faiths, increasing their perceptiveness of the cultural backgrounds within which they live.

This study has seen Religious Education as a subject that deals with the religious and ethical attitude and values that strengthen individual choices and behavior such as relationships, social policies and practices (e.g. offense and penalty), and the notion and outline of health (e.g. the application of drugs). Religious Education looks at the voluntary and charitable activities that make up a healthy society and provide opportunities for the development of lively citizenship and involvement in society. Beliefs about the nature of humanity and the world influence how we systematize ourselves and communicate to others in the vicinity both nationally and internationally. Matter in religious education therefore contributes to social and political responsiveness.

The last chapter of this thesis is meant to illustrate a typical example of a primary school curriculum that will help develop a young child's understanding of religion. The early stage of primary school can also adopt the practice of teaching different types of religion in other for children to know that they are different types of religion in the world. My syllabus is structured to suite a primary school in Edo State, Nigeria.

\section{References}

[1] Fagan, P.F. (2006): "Why Religion Matters: The Impact of Religious Practice on Social Stability," Heritage Foundation Backgrounder No. 1064,

[2] Brown, D.R., and Gary, L.E. (1991): "Religious Socialization and Educational Attainment among African Americans: An Empirical Assessment," Journal of Negro Education, Vol. 60, No. 3 (www.manhattan-institute.org/html/jpr-98-2.htm

[3] Novak, M. (2001): On Two Wings: Humble Faith and Common Sense at the American Founding (San Francisco: Encounter Books)

[4] Richardson, J.D. (1907): Compilation of Messages and Papers of the Presidents, 1789-1897 (Washington, D.C.: U.S. Government Printing Office, 1907), Vol. 1, p. 213.

[5] King, V. (2003): "The Influence of Religion on Fathers' Relationships with Their Children," Journal of Marriage and Family, Vol. 65, No. 2 pp. 382-395.

[6] Wade, L.D. (2002): "Relationship Dissolution as a Life Stage Transition: Effects on Sexual Attitudes and Behaviors," Journal of Marriage and Family, Vol. 64, No. 4 pp. 898-914.

[7] Rostosky, S.S., Regnerus, M.D. and Wright, M.L.C. (2003): "Coital Debut: The Role of Religiosity and Sex Attitudes in the Add Health Survey," Journal of Sex Research, Vol.40, No. 4 pp. 358-367.

[8] Kraaykamp, G. (2002): "Trends and Countertrends in Sexual Permissiveness: Three Decades of Attitude Change in the Netherlands: 1965-1995," Journal of Marriage and Family, Vol. 64, No. 1 pp. 225-239. 
[9] Thornton, A. (1989): "Religious Participation and Adolescent Sexual Behavior and Attitudes," Journal of Marriage and Family, Vol. 51, No. 3 pp. 641-653.

[10] Blinn-Pike, L. (1999): "Why Abstinent Adolescents Report They Have Not Had Sex: Understanding Sexually Resilient Youth," Family Relations, Vol. 48, No. 3 pp. 295-301.

[11] Billy, J.O.G (1994): "Contextual Effects on the Sexual Behavior of Adolescent Women," Journal of Marriage and Family, Vol. 56, No. 2 pp. $387-404$.

[12] Johnson, B.R., Tompkins, R.B. and Webb, D. (2002) "Objective Hope-Assessing the Effectiveness of Faith-Based Organizations: A Systematic Review of the Literature," Manhattan Institute for Policy Research, Center for Research on Religion and Urban Civil Society, 2002, at www.manhattan-institute.org/pdf/crrucs_objective_hope.pdf (June 30, 2005).

[13] Waller, M. (2001): "High Hopes: Unmarried Parents' Expectations about Marriage," Children and Youth Services Review, Vol. 23, No. 6 pp. $457-484$.

[14] Abrahamse, A.F. (1988): Beyond Stereotypes: Who Becomes a Single Teenage Mother? (Santa Monica, Calif.: Rand Corporation,), pp. 37-50.

[15] Donahue, M.J. (1988): "Aggregate Religiousness and Teenage Fertility Revisited: Reanalyzes of Data from the Guttmacher Institute," presented at the Annual Meeting of the Society for the Scientific Study of Religion, Chicago,

[16] Koenig, H.G., George, L.K., Cohen, H.J., Hays, J.C., Larson, D.B. and Blazer, D.G. (1998): "The Relationship Between Religious Activities and Cigarette Smoking in Older Adults," Journals of Gerontology: Medical Sciences, Vol. 53A, Issue 6 pp. M426-M434.

[17] Feroz Ahmed, Diane R. Brown, Lawrence E. Gary, and Frough Saadatmand, "Religious Predictors of Cigarette Smoking: Findings for African American Women of Childbearing Age," Behavioral Medicine, Vol. 20, No. 1 (Spring 1994), pp. 34-43.

[18] Gartner, J., Larson, D.B. and Allen, G. (1991): "Religious Commitment and Mental Health: A Review of the Empirical Literature," Journal of Psychology and Theology, Vol. 19, Issue 1 pp. 6-25.

[19] Hasin, D. Endicott, J. and Lewis, C. (1985): "Alcohol and Drug Abuse in Patients with Affective Syndrome," Comprehensive Psychiatry, Vol. 26,Issue 3 pp. 283-295.

[20] Achaempong, Y. A. and Bahr, S. J. (1986): "Religion, Family, and Drug Abuse," Sociological Perspectives, Vol. 29 pp. 53-73,

[21] Free, M.D. (1994): "Religiosity, Religious Conservatism, Bonds to School, and Juvenile Delinquency among Three Categories of Drug Users," Deviant Behavior, Vol. 15, No. 2 pp. 151-170.

[22] Brizer, D.A. (1993): "Religiosity and Drug Abuse Among Psychiatric Inpatients," American Journal of Drug and Alcohol Abuse, Vol. 19 , No. 3 pp. 337-345.

[23] Carroll, S. (1993): "Spirituality and Purpose in Life in Alcoholism Recovery," Journal of Studies on Alcohol, Vol. 54, No. 3 pp. 297301.

[24] Foshee, V.A. and Hollinger, B.R. (1996): "Maternal Religiosity, Adolescent Social Bonding, and Adolescent Alcohol Use," Journal of Early Adolescence, Vol. 16, No. 4 pp. 451-468.

[25] Lorch, B.R. and Hughes, R.H. (1985): "Religion and Youth Substance Use," Journal of Religion and Health, Vol. 24, No. 3 pp. 197208.

[26] Johnson, B. (2006): "A Better Kind of High: How Religious Commitment Reduces Drug Use Among Poor Urban Teens," Manhattan Institute for Policy Research, Center for Research on Religion and Urban Civil Society Report No. 2000-2, at www.manhattaninstitute.org/html/cr_12.htm (December 6, 2006).

[27] Adlaf, E.M. (1985): "Drug Use and Religious Affiliation: Feelings and Behavior," British Journal of Addiction, Vol. 80, No. 2 pp. $163-171$.

[28] Thompson, R.D. (1994): "Teen Challenge of Chattanooga, Tennessee: Survey of Alumni," University of Tennessee at Chattanooga

[29] Bicknese, A.T. (1999): "The Teen Challenge Drug Treatment Program in Comparative Perspective," doctoral dissertation, Northwestern University

[30] Ellison, C.G., Boardman, J.D., Williams, D.R. and Jackson, J.S. (2001): "Religious Involvement, Stress, and Mental Health: Findings from the 1995 Detroit Area Study," Social Forces, Vol. 80, Issue 1 pp. 215-249.

[31] Jang, S.J. and Johnson, B.R. (2004): "Explaining Religious Effects on Distress Among African Americans," Journal for the Scientific Study of Religion, Vol. 43, No. 2 pp. 239-260.

[32] Krause, N., Ellison, C.G., Shaw, B.A., Marcum, J.P. and Boardman, J.D. (2001): "Church-Based Social Support and Religious Coping," Journal for the Scientific Study of Religion, Vol. 40, No. 4 pp. 637-656.

[33] Markstrom, C.A. (1999): "Religious Involvement and Adolescent Psychosocial Development," Journal of Adolescence, Vol. 22, No. 2 (April 1999), pp. 205-221.

[34] Ellison, C.G. (1995): "Race, Religious Involvement, and Depressive Symptomatology in a Southeastern U.S. Community," Social Science and Medicine, Vol. 40, No. 11 pp. 1561-1572.

[35] Wright, L.S. (1993): Christopher J. Frost, and Stephen J. Wisecarver, "Church Attendance, Meaningfulness of Religion, and Depressive Symptomatology Among Adolescents," Journal of Youth and Adolescence, Vol. 22, No. 5 pp. $559-568$.

[36] Tovato, F. (1990): "Domestic/Religious Individualism and Youth Suicide in Canada," Family Perspective, Vol. 24 , No. 1 pp. 69-81.

[37] Harker, K. (2001): "Immigration Generation, Assimilation, and Adolescent Psychological Well-Being," Social Forces, Vol. 79, No. 3 pp. 969-1004.

[38] Regnerus, M.D. (2003):"Religion and Positive Adolescent Outcomes: A Review of Research and Theory," Review of Religious Research, Vol. 44, No. 4 pp. 394-413.

[39] Hummer, R.A., Rogers, R.G., Nam, C.B. and Ellison, C.G. (2001): "Religious Involvement and U.S. Adult Mortality," Demography, Vol. 36, No. 2pp. 273-285.

[40] Hummer, R.A., Ellison, C.G., Rogers, R.G., Moulton, B.E. and Romero, R.R. (2004): "Religious Involvement and Adult Mortality in the United States: Review and Perspective," Southern Medical Journal, Vol. 97, No. 12 pp. 1223-1230.

[41] Levin, J.S. and Schiller, P.L. (1987): "Is There a Religious Factor in Health?" Journal of Religion and Health, Vol. 26, No. 1 pp. 935 .

[42] Comstock, G.W. and Patridge, K.B. (1972): "Church Attendance and Health," Journal of Chronic Diseases, Vol. 25, No. 12 pp. 665672.

[43] Regnerus, M.D. (2001): "Making the Grade: The Influence of Religion upon the Academic Performance of Youth in Disadvantaged Communities," University of Pennsylvania, Center for Research on Religion and Urban Civil Society Report No.3

[44] Regnerus, M.D. (2000): "Shaping Schooling Success: Religious Socialization and Educational Outcomes in Metropolitan Public Schools," Journal for the Scientific Study of Religion, Vol. 39, Issue 3 pp. 363-370.

[45] Muller, C. and Ellison, C.G. (2001): "Religious Involvement, Social Capital, and Adolescents' Academic Progress: Evidence from the National Education Longitudinal Study of 1988," Sociological Focus, Vol. 34, No. 2 pp. 155-183. 
[46] Neal, D. (1998): "What Have We Learned About the Benefits of Private Schooling?" Federal Reserve Bank of New York Economic Policy Review, Vol. 4, No. 1 pp. 79-86.

[47] Freeman, R.B. (1995): "Who Escapes? The Relation of Churchgoing and Other Background Factors to the Socioeconomic Performance of Black Male Youths from Inner-City Tracts," National Bureau of Economic Research Working Paper No. 1656

[48] Sloane, D.M. and Potvin, R.H. (1986): "Religion and Delinquency: Cutting Through the Maze," Social Forces, Vol. 65, No. 1 pp. 87105.

[49] Regnerus, M.D., Smith, C. and Sikkink, D. (1998): "Who Gives to the Poor? The Influence of Religious Tradition and Political Location on the Personal Generosity of Americans toward the Poor," Journal for the Scientific Study of Religion, Vol. 37 , No. 3 pp. 481-493.

[50] Lester, D. (1987): "Religiosity and Personal Violence: A Regional Analysis of Suicide and Homicide Rates," The Journal of Social Psychology, Vol. 127, No. 6 pp. 685-686.

[51] Johnson, B.R. (2004): "Religious Programs and Recidivism among Former Inmates in Prison Fellowship Programs: A Long-Term Follow-Up Study," Justice Quarterly, Vol. 21, No. 2 pp. 329-354.

[52] Bergin, A.E. (1991): "Values and Religious Issues in Psychotherapy and Mental Health," The American Psychologist, Vol. 46, No. 4 pp. 394-403.

[53] Halley, H.H. (2000): Halley's Bible Handbook, 25th ed., Zondervan Publishing House

[54] The Holy Bible, (1982): Luke 24:44, New King James Version, Thomas Nelson Publishers,

Bruce, F.F. (1960): The New Testament Documents: Are They Reliable? 5th rev. ed., Intervarsity Press, 21-28.

[56] Barnes, P. (2001): Reforming Religious Education in Northern Ireland. A critical Review: British Journal of Religious Education. Vol.19. Pg. 81

[57] Bastide, D. (1987): Religious Education 5-12. Basingstoke: Taylor \& Francis

[58] López-Muñiz, J. L. M., Groof, J. D. \& Lauwers, G. (2006): Religious Education in Public Schools: Study of Comparative law. (European Association for Education law \& Policy) Vol. 5. Netherlands: Springer.

[59] Qualifications and curriculum Development Agency (QCDA) (1993): Primary Religious Education (RE): Inclusion

[60] Gallagher, A.M. (1989). The relationship between research and policy: an example from Northern Ireland. The Psychologist: Bulletin of the British Psychological Society, 2(2), 62-63.

[61] Gallagher, P. (1987). The Future for Further Education in Northern Ireland; in Osborne, R.D., Cormack, R.J. and Miller, R.L. (editors) Education and Policy in Northern Ireland. Belfast: Policy Research Institute.

[62] Greer, J.E. (1972). A Questioning Generation. Belfast: Church of Ireland Board of Education.

[63] Greer, J.E. (1978). Religious Education in State Primary Schools in Northern Ireland. The Northern Teacher, 13(2), 11-16.

[64] Greer, J.E. (1979/80). Religious Education in State Primary Schools in Northern Ireland. The Northern Teacher, 13(3), 7-11.

[65] Greer, J.E. (1983). The County School in Northern Ireland. The Northern Teacher, 14(1), 6-11.

[66] Greer, J.E. and Brown, W. (1981). The inspection of religious education in Northern Ireland schools. The Northern Teacher, 13(4), 37.

[67] Darby, J., Murray, D., Batts, D., Dunn, S., Farren, S. and Harris, J. (1977). Education and Community in Northern Ireland: Schools Apart? Coleraine: the New University of Ulster

[68] Teare, S.M. and Sutherland, A.E. (1988). At Sixes and Sevens: a study of the curriculum in the upper primary school. Belfast: Northern Ireland Council for Educational Research

[69] Gallagher, P. (1987). The Future for Further Education in Northern Ireland; in Osborne, R.D., Cormack, R.J. and Miller, R.L. (editors) Education and Policy in Northern Ireland. Belfast: Policy Research Institute

[70] Hull, J.M. (1993): The Nature of Religious Education. Distinctive Aspects of Baha'i Education: Proceedings of the Third Symposium on Baha'i Education, The Baha'i Publishing Trust,

[71] Wilkins, L. (2005): "School worship: from sports to death". BBC News website. BBC.

[72] Goff, H. (2008): "Call to offer faith class choice". BBC News website. British. Broadcasting Corporation.

[73] Department for Children, Schools and Families, (2008): "Religious Education collective worship and the right to withdraw". Teachernet. Department for Children, Schools and Families.

[74] Department for Children, Schools and Families, (2005). "Collective worship". Teachernet. Department for Children, Schools and Families.

[75] "BHA Briefing 2006/12: Education and Inspections Bill" (PDF). BHA Briefing. British Humanist Association.

[76] Qualifications and Curriculum Authority, (2004). "Religious Education: non-statutory framework". National Curriculum Website. Qualifications and Curriculum Authority.

[77] Briggs, C.A. (1913): The fundamental Christian faith: the origin, history and interpretation of the Apostles' and Nicene creeds. C. Scribner's sons Online: http://books.google.com/books?id=VKMPAAAAIAAJ

[78] Cummins, Duane D. (1991). A handbook for Today's Disciples in the Christian Church (Disciples of Christ) Revised Edition. St Louis, MO: Chalice Press. ISBN 0-8272-1425-1.

[79] Ron Rhodes (2005): The Complete Guide to Christian Denominations, Harvest House Publishers, 2005, ISBN 0-7369-1289-4

[80] Eisenbaum, Pamela (Winter 2004). "A Remedy for Having Been Born of Woman: Jesus, Gentiles, and Genealogy in Romans". Journal of Biblical Literature 123 (4): 671-702. doi:10.2307/3268465. http://www.sbl-site.org/assets/pdfs/JBL1234.pdf. Retrieved 2009-04-03.

[81] Wright, N.T. What Saint Paul Really Said: Was Paul of Tarsus the Real Founder of Christianity? (Oxford, 1997), p. 121.

[82] Johnson, Elliott (1990). Expository hermeneutics : an introduction. Grand Rapids Mich.: Academic Books. ISBN 9780310341604.

[83] Terry, Milton (1974). Biblical hermeneutics : a treatise on the interpretation of the Old and New Testaments. Grand Rapids Mich.: Zondervan Pub. House. p. 205

[84] Elwell, Walter A. (1984). Evangelical Dictionary of Theology. Grand Rapids, Mich.: Baker Book House. ISBN 0801034132. p. 565

[85] GREER, J.E. (1978). Religious Education in State Primary Schools in Northern Ireland. The Northern Teacher, 13(2), 11-16.

[86] GREER, J.E. (1979/80). Religious Education in State Primary Schools in Northern Ireland. The Northern Teacher, 13(3), 7-11

[87] Chambers, Mortimer; Crew, Herlihy, Rabb, Woloch. The Western Experience. Volume II: The Early Modern Period. Alfred A. Knopf (1974). ISBN 0-394-31734-3.

[88] Coffey, John. Persecution and Toleration in Protestant England 1558-1689. Pearson Education (2000).

[89] Cross, F. L.; Livingstone, E. A. (ed.). The Oxford Dictionary of the Christian Church. Oxford University Press (1997). ISBN $019211655 \mathrm{X}$

[90] Creed, N. (20070: ". Encyclopedia Britannica Online. Encyclopædia Britannica. 


\section{Internet References}

http://www.teachernet.gov.uk/management/atoz/r/recollectiveworshipandtherighttowithdraw/. Retrieved 200802-07.

http://www.teachernet.gov.uk/management/atoz/c/collectiveworship/. Retrieved 2008-02-07.

http://www.humanism.org.uk/uploadedFiles/cms/store//Campaigns/article_ParliamentaryBriefings_files/ATTA CHMENTS/Amendment\%20205.pdf. Retrieved 2008-02-07.

http://news.bbc.co.uk/1/hi/uk/4693129.stm. Retrieved 2008-02-07.

http://www.nc.uk.net/webdav/harmonise?Page/@id=6004\&Subject/@id=7881. Retrieved 2008-02-07.

http://news.bbc.co.uk/1/hi/education/7311178.stm. Retrieved 2008-03-27.

http://www.covenanter.org/JMcauley/secularversuschristianed.htm retrieved 26-03-2010

http://www.religiouseducationcouncil.org/content/view/139/56/ retrieved 26-03-2010

http://en.wikipedia.org/wiki/Christianity retrieved 27-03-2010 retrieved 10-January 2010

http://www.christianaction.org.za/newsletter_uca/uca-artic_christian_education.htm retrieved 26-03-2010 retrieved 10-January 2010

http://www.cornerstonekingman.ca/benefits_of_christian_education retrieved 18-March 2010

http://www.christianeducation.org.uk/pdfs/ce_christian_perspectives_jun08.pdf retrieved 18-March 2010

http://www.calvin.edu/academic/education/news/publications/monoweb/debeer 1.htm\#_Toc487506876

retrieved 18-March 2010

http://www.allaboutthejourney.org/history-of-the-bible.htm retrieved 18-March 2010

http://www.ascd.org/publications/books/198190/chapters/The_Bible_and_World_Religions.aspx retrieved 18March 2010

http://cain.ulst.ac.uk/csc/reports/mm1f2.htm retrieved 29-August 2009

http://www.qcda.gov.uk/7313.aspx retrieved 29-August 2009

http://rel-ed.acu.edu.au/ren/agend.htm retrieved 20-March 2010

http://www.johnmhull.biz/The\%20Nature\%20of\%20Religious\%20Education.html retrieved 20-March 2010

http://www.bukisa.com/articles/134701_the-importance-of-bible-study-for-your-children retrieved 20 March 2010

http://www.anthony-roper.kent.sch.uk/aboutus/Religious\%20Education\%20Policy1.pdf retrieved 20 March 2010

http://www.heritage.org/Research/Reports/2006/12/Why-Religion-Matters-Even-More-The-Impact-of-

Religious-Practice-on-Social-Stability retrieved 20 March 2010

http://www.britannica.com/eb/article-9055702. Retrieved 2007-12-31.

www.heritage.org/research/religion/upload/bg_1064.pdf . Retrieved 26-March 2010 